IZA DP No. 8383

How Far Away Is a Single European Labor Market?

Annabelle Krause

Ulf Rinne

Klaus F. Zimmermann

August 2014

Forschungsinstitut zur Zukunft der Arbeit Institute for the Study of Labor 


\title{
How Far Away Is a Single European Labor Market?
}

\author{
Annabelle Krause
}

$I Z A$

Ulf Rinne

IZA

\author{
Klaus F. Zimmermann \\ IZA and University of Bonn
}
Discussion Paper No. 8383
August 2014

IZA
P.O. Box 7240
53072 Bonn
Germany

Phone: +49-228-3894-0

Fax: +49-228-3894-180

E-mail: iza@iza.org

Any opinions expressed here are those of the author(s) and not those of IZA. Research published in this series may include views on policy, but the institute itself takes no institutional policy positions. The IZA research network is committed to the IZA Guiding Principles of Research Integrity.

The Institute for the Study of Labor (IZA) in Bonn is a local and virtual international research center and a place of communication between science, politics and business. IZA is an independent nonprofit organization supported by Deutsche Post Foundation. The center is associated with the University of Bonn and offers a stimulating research environment through its international network, workshops and conferences, data service, project support, research visits and doctoral program. IZA engages in (i) original and internationally competitive research in all fields of labor economics, (ii) development of policy concepts, and (iii) dissemination of research results and concepts to the interested public.

IZA Discussion Papers often represent preliminary work and are circulated to encourage discussion. Citation of such a paper should account for its provisional character. A revised version may be available directly from the author. 
IZA Discussion Paper No. 8383

August 2014

\section{ABSTRACT \\ How Far Away Is a Single European Labor Market?}

A Single European Labor Market, particularly involving the free movement of workers within Europe, has been a goal of the European community since the 1950s. Whereas it may entail opportunities and drawbacks alike, the benefits - such as greater economic welfare for most citizens - are supposed to outweigh the losses. However, over fifty years after the aim was first established, a Single European Labor Market has not yet been achieved. This paper gives an overview of current European macroeconomic trends, with a particular focus on the Great Recession, and also explores the drivers of and obstacles to labor mobility. Complementarily, it analyzes the results of a unique opinion survey among labor market experts, as well as formulates policy recommendations to enhance mobility. The development of a Single European Labor Market is also discussed in relation to the German model.

JEL Classification: J40, J61, J68

Keywords: European labor market integration, worker mobility, economic crisis, economic migration, German model

Corresponding author:

Klaus F. Zimmermann

IZA

P.O. Box 7240

53072 Bonn

Germany

E-mail: Zimmermann@iza.org 


\section{Introduction}

Since the 1950s, Germany has played a crucial role in the European integration movement and the Single European Labor Market concept. Consequently, this challenges the German model. Either Germany serves as a role model to which other EU countries converge, bringing the country into an undesired leadership role, or the German model itself needs adjustments to meet the demands of integration. Hence, this paper attempts to put the German model in a European perspective. More specifically, it focuses on the development of a Single European Labor Market and its relation to the German model.

According to Vitols (2005), the German model is traditionally characterized by a cooperative (or corporatist) approach to industrial modernization. It differs from the market-based approach in the United States and the United Kingdom, and from the more regulatory approach in France and Japan. The German model is based on a collective partnership between the state, business and trade unions. A prime example for this interrelation is the German dual vocational training system, which heavily depends on the support from employers, trade unions and the government regarding regulation and funding (Zimmermann et al. 2013). However, in the beginning of the 1990s, the German model was challenged by four developments: (1) German reunification, (2) continuing shifts in global production and financial systems, (3) a crisis in the welfare state, and (4) European integration (Vitols 2005).

European integration with its single market is supposed to guarantee the free movement of goods, services, capital and workers. ${ }^{1}$ The idea of the free movement of workers, however, was developed long before the term "Single European Market" was established in 1992. In 1951, the Treaty of Paris allowed for free movement of workers in the coal and steel industries, followed by the Treaty of Rome in 1957 establishing the right for free movement of workers in the member states of the European Economic Community. ${ }^{2}$ By fostering growth through a more efficient allocation of labor between countries with labor surpluses and those with labor shortages, the free movement of labor would most likely create higher economic welfare (Zimmermann 2005). Moreover, from a social perspective, mobility within Europe potentially increases the European social-cultural integration and strengthens European identity (Bonin et al. 2008).

\footnotetext{
${ }^{1}$ For more background information on the "Single Market Act" established in 1992, see http://ec.europa.eu/internal market/smact/index en.htm.

${ }^{2}$ Full texts of the treaties can be found at http://www.cvce.eu/obj/treaty establishing the european coal and steel community paris 18 april 1951-en-11a21305-941e-49d7a171-ed5be548cd58.html and http://www.cvce.eu/obj/treaty establishing the european economic community rome 25 march 1957-en-cca6ba28-0bf3-4ce6-8a76-6b0b3252696e html.
} 
However, even decades after establishing the idea and legislation for a Single European Labor Market, academic experts and policy makers agree that this goal is far from being accomplished (see, e.g., European Commission 2012; Dhéret et al. 2013; Zimmermann 2013a). ${ }^{3}$ In other words, labor mobility within Europe is not high enough. Bonin et al. (2008) emphasize that while too little mobility may be accompanied with reduced adaptability, unfilled vacancies and unused growth opportunities, too much mobility may negatively affect national labor markets and create social tensions. Thus, it appears important to consider an optimal level of mobility, although it is difficult to judge that exact level.

The discussion about the obstacles to labor mobility within Europe is not new either. For example, Zimmermann (1995) and Heinz and Ward-Warmedinger (2006) discuss the following barriers: language and cultural differences, the monetary costs of moving, inefficient housing markets, the lack of harmonization of social security benefits including pensions, insufficient international recognition of professional qualifications, disparate education systems and the lack of transparency in job openings. Most of these reasons distinguish the European situation from the labor market in the United States (US), where mobility is much higher. Importantly, US mobility is not only higher than within Europe, but also higher than within European countries (Bonin et al. 2008). However, the US has become less mobile since the crisis, whereas Europe became more flexible after 2004 due to the EU Eastern enlargement (Zimmermann 2013a). Jauer et al. (2014) show, for example, that intra-European migration flows could be able to absorb up to one fourth of the asymmetric shocks to unemployment induced by the Great Recession.

This development has been accompanied by rising tensions over free labor mobility within the European Union. First, there is the well-observed long-term rise in EU-skepticism (Ritzen and Zimmermann 2013; Ritzen, Zimmermann and Wehner 2014). ${ }^{4}$ Identifying people in European member countries who hold the European ideal is decelerating, and many associate this with the failure of the Single European Labor Market. Second, and in spite of all the positive findings for the European labor markets due to the EU Eastern enlargements, there is a rising mistrust in the benefits of labor mobility. In 2013, four governments-those of Germany, Austria, the United Kingdom and the Netherlands-raised concerns in a public letter to the EU Council regarding a perceived threat of welfare migration. ${ }^{5}$ In 2014, the Swiss population

\footnotetext{
${ }^{3}$ See Figure 8 for a very up-to-date opinion poll (IZA Expert Opinion Survey 2014) on this question among academic and policy labor market experts. Section 4 provides survey details. ${ }^{4}$ The rise in EU-skepticism is also reflected by the outcome of the 2014 European Parliament elections.

${ }^{5}$ For a public version of the letter sent to the Irish Presidency of the European Council, see http://docs.dpaq.de/3604-130415 letter to presidency final 1 2.pdf.
} 
voted to reintroduce immigration quotas, therefore going against free mobility, as defined in the collaborative treaties between Switzerland and the European Union. These developments suggest a potential EU degeneration, unless the public can be convinced of the merits arising from free inner-European labor mobility.

What are the risks and opportunities related to a Single European Labor Market? Does the Great Recession play a role in this context? Which obstacles to labor mobility prove to be the most severe? Is Europe converging to the German model or should Germany converge to a European model in the face of a Single European Labor Market? The aim of this paper is to collect answers to these questions and give policy recommendations that are useful toward reaching the goal of the free movement of labor. We combine a descriptive analysis of macroeconomic trends within Europe and a literature review with the analysis of a unique and fresh expert opinion survey on European labor market integration conducted specifically for this study.

This paper is organized as follows: The next section describes the evolution of several macroeconomic indicators and labor reform policies in Europe. In Section 3 we discuss the concept of the Single European Labor Market, accompanied with a literature overview on the topic. Section 4 presents results of a new IZA Expert Opinion Survey among labor market experts from academia and policy. Section 5 concludes.

\section{Convergence in Macroeconomic Factors and Policies in Europe}

To obtain an overview of the development of important macroeconomic indicators in Europe in recent years and their potential convergence, we discuss some stylized facts in this section. First, we more thoroughly investigate two general macroeconomic indicators, namely GDP and the Gini coefficient. Second, we present the evolution over time of indicators that are more closely related to national labor markets, such as the unemployment rate and the size of labor market policy expenditures. As labor mobility is considered to be the key dimension of the Single European Labor Market, we also provide evidence on net migration flows within Europe. Moreover, we describe possible patterns of convergence with respect to labor reform policies.

\subsection{Macroeconomic Factors}

Figure 1 plots the evolution of GDP between 2005 and 2012 for selected European countries. It shows a relatively similar development until 2008 when the economic crisis hit, whereas afterwards the evolution of the countries' GDP differs considerably. One can see a clear divide in 2012 between Germany and Southern 
European countries such as Greece, Italy or Portugal. One reason behind these different evolutions is Germany's fast recovery from the Great Recession and its relatively stable labor market throughout it (Rinne and Zimmermann 2012). On the other hand, Southern European countries, in particular Greece, show no signs of recovery until the end of the observation period.

Figure 2 displays the Gini coefficients, as measures for income inequality, for selected European countries and their evolution from 2005 to 2012. In most countries, there was a slight increase in income inequality over time, while this increase was much steeper in some countries (e.g., Bulgaria, particularly between 2005 and 2008) and much smoother in others (e.g., Denmark). Poland experienced a small, but constant decrease in the Gini coefficient over time. Even though the numbers in 2012 still ranged from 25.4 in the Netherlands to 35.0 in Spain, there seems to have been a slight convergence to more similar national income inequalities across countries.

Turning to labor market trends in Figure 3, we depict the average unemployment rate of the European Union as well as that of selected European countries over time. The evolution shows a clear trend: Before the crisis hit in 2008, unemployment rates were converging towards each other while after 2008, they again began diverging. In particular, the cases of Spain and Germany are interesting. Whereas Germany had a slightly higher unemployment rate than Spain in 2005, by 2013 there was a difference of about 20 percentage points: The unemployment rate was 25 percent in Spain while it was about 5 percent in Germany. If any convergence in unemployment rates had emerged, the Great Recession reversed this trend.

As mobility presents the key factor in the discussion about European labor market integration, we plot net migration flows from EU27 nationals to selected European countries in Figure 4. Net migration flows have generally decreased throughout the Great Recession beginning in 2008. In particular, Italy and Spain experienced a sharp drop in net migration. Poland experienced negative net migratory flows throughout the observation period, with their absolute values increasing during the crisis. The trend for Germany is slightly different. Having had experienced a continuous decrease in net migration flows until the lowest point in 2008 with a negative net flow of about 50,000 individuals, there has been an increasing trend since 2009. In 2011 the value was at a new high of almost 150,000 individuals between 2002 and 2011. Accordingly, Dhéret et al. (2013) identify Germany as a new "core destination" in Europe. Furthermore, they identify two periods during and after the crisis: the first period between 2008 and 2010 when migration flows decreased in the whole of Europe, and the second period starting in 2010 when some economies (mostly northern countries) started to recover and others (mostly southern countries) were still affected, leading to a so-called south- 
north migration. For example, Bertoli et al. (2013) provide evidence that almost 80 percent of the recent increase in migration to Germany was caused by deteriorating conditions in alternative destinations. The Great Recession has thus diverted migration flows within Europe-and to a large extent to Germany.

In addition, within the observation period considered in Figure 4, two important EU enlargements took place: The accession of the EU8 in 2004 and of the EU2 in 2007. Subsequent east-west migration evolved mainly via two migration corridors: Migrants from the EU8 went to Germany, Ireland and the UK, whereas migrants from the EU2 went to Italy and Spain (Dhéret et al. 2013). Moreover, the crisis seems to have created a new attractiveness of destinations outside Europe. Dhéret et al. (2013) show that some migrants-in particular from Greece, Ireland, Portugal and Spain-have been choosing destination countries outside of Europe more often since 2010. Furthermore, Galgoczi and Leschke (2012) find that the stock of the EU10 population in EU15 countries has continued to increase during the crisis, except in Ireland and Spain. This stock of EU10 migrants were hit more severely by the crisis. Importantly, the authors find strong evidence of migrant overqualification, so that greater labor market mobility alone may not lead to a more efficient Single European Labor Market, at least not in the short run. ${ }^{6}$

\subsection{Labor Reform Policies}

Figure 5 shows the evolution of labor market policy expenditures as a percentage of GDP in selected European countries. In the years before the crisis, expenditures for labor market policies decreased in most countries or stayed rather constant. This development led to a slight convergence to an average expenditures share of about 1.5 to 2.5 percent of GDP. During the crisis, most countries increased their expenditures share, particularly in 2009 and 2010, showing a stronger governmental emphasis on labor market policies. However, these increases in expenditures rates differed greatly, so that there was again high dispersion between countries in 2011 . The percentage values ranged from 0.3 percent in Romania to 3.7 percent in Denmark in 2011. Thus, expenditure shares were almost as different as in 2004. Note that these are expenditures for all types of labor market policies. Regarding a potential trend to passive or active policies, there is evidence that the European

\footnotetext{
${ }^{6}$ Overqualification is a general issue in labor markets, which is particularly relevant for migrants (see Piracha and Vadean, 2013; Piracha, Tani and Vadean, 2012). Human capital is not used in the most efficient way. Reasons may include slow adjustment, insufficient recognition of degrees or lower qualities of the degrees. See Biavaschi and Zimmermann (2014) for a similar evaluation.
} 
Employment Strategy led to shifts from passive to more active labor market policies in Europe between 1985 and 2005 (Vliet and Koster 2011). ${ }^{7}$

Considering the German model during the Great Recession, Germany is one of very few countries that weathered the economic crisis without major disruptions on its labor market (Rinne and Zimmermann 2012). The country may thus be regarded as a showcase, or "North Star," of labor market policy and reforms (Rinne and Zimmermann 2013; Zimmermann 2013b). One possible pattern of convergence within Europe is thus that other countries copy the German model. However, the German reforms were themselves inspired by reforms in the late 1990s and early 2000s in other European countries (e.g., the United Kingdom). Additionally, one should keep in mind that there is very likely no one-size-fits-all solution, but that models have to be developed for specific country contexts (Zimmermann 2013b).

Nonetheless, Germany indeed appears as a role model for other countries to draw upon a number of features of the German model. These features include the emphasis on work incentives, individual responsibility, flexibility as well as social cohesion. However, even the German model will have to change in the future (e.g., because of demographic pressure; Rinne and Zimmermann 2013). Convergence in reform policies should thus be viewed as a dynamic process, where the reference point for a potential Single European Labor Market will change over time.

\section{A Single European Labor Market}

A Single European Labor Market involves in particular the free movement of workers. Theoretically, migration contributes to the functioning of a market economy as an adjustment mechanism. Through labor mobility the capital-to-labor ratio and regional income disparities are equalized. Similarly, Mundell (1961) describes in his seminal paper high factor mobility (capital and labor) as an essential determinant of a single currency area for economic stability and to absorb shocks.

At the micro level, the individual migration decision is seen as an investment decision. Potential migrants calculate the present discounted value of expected returns in the potential destination and in the origin region. If the net gain from moving, including migration costs, is higher than the expected utility of not moving, the individual will decide to migrate. Such models and their background are discussed in more detail in Sjaastad (1962) and Borjas (1989), among others (Constant and Zimmermann [2013] contain further references).

\footnotetext{
${ }^{7}$ For a description of the European Employment Strategy, which seeks to create more and higher quality employment throughout the EU by discussing and coordinating national employment policies, please see http://ec.europa.eu/social/main.jsp?catld=101.
} 
How are these theoretical considerations related to the situation in Europe? What are the benefits and possible drawbacks of a Single European Labor Market? In this section, we focus first on these questions, subsequently turning our attention to the drivers and obstacles of migration, before we discuss the role of vocational education.

\subsection{Costs and Benefits of Intra-EU Migration}

With respect to the costs and benefits of labor mobility, it is useful to distinguish between the economic, demographic and social perspective (Bonin et al. 2008; Zimmermann 2013a). From an economic point of view, enhanced labor mobility serves to balance labor supply and demand between regional labor markets. This may result in better skill matches and lead to higher returns of human capital formation; in turn, it increases incentives to invest in human capital, innovation and entrepreneurship, as well as fosters growth for the majority of people.

Potential drawbacks of increased labor mobility in the receiving countries are increased competition that puts downward pressure on wages as well as the threat of welfare migration (Bonin et al. 2008; Zimmermann 2013a). However, there appears to be no negative effect of immigration on native employment and wages (e.g., Altonji and Card 1991; Bonin 2005; Kahanec and Zimmermann 2009; Kahanec 2013; Zimmermann 2013a). Likewise, Brunow and Brenzel (2012) show that immigration has a positive net effect on regional income. Moreover, they find that cultural diversity among foreign-born people also produces income gains by increasing the supply of different skills, knowledge and tasks. ${ }^{8}$ Giulietti and Wahba (2013) provide an extensive overview of the literature on welfare migration and state that the empirical evidence of welfare migration is limited. Moreover, when evidence of a welfare magnet is found, it is rather small.

Potential drawbacks for the sending countries may be a "brain-drain" shock, which can be problematic for long-term growth. However, this shock may be offset through remittances, temporary rather than permanent migration and migrants acting as middlemen linking businesses in the sending and receiving country (Bonin et al. 2008; Brenke 2011). Elsner (2013) shows in the context of EU enlargement flows to the United Kingdom and Ireland that emigration had a significant positive effect on the wages of stayers.

Hence, for mobility to be beneficial, the associated gains would need to outweigh the losses. The European case is judged to be a win-win situation, meaning a Single European Labor Market would bring more good than bad for most people (Bonin et al. 2008; Dhéret et al. 2013).

\footnotetext{
${ }^{8}$ Parotta et al. (2014) is another example for the literature demonstrating that ethnic and cultural diversity are positively related to innovative activities.
} 
However, along with the economic perspective, one should also take into account the demographic and social perspective (Bonin et al. 2008). Regarding the demographic situation in Europe, migration certainly represents one way to at least partially reduce the effects of an aging society and population decline. However, as almost all European countries face these trends, there is not much room to counteract demographic trends with labor mobility within Europe (Bonin et al. 2008). There would be more scope for migration from non-EU countries with respect to the demographic trend. However, there is some evidence for a "Fortress Europe": liberalizing mobility within Europe, but keeping restrictions with respect to migration from outside Europe (Marques 2010). Next to migration of EU-nationals, intra-EU migration of third-country nationals becomes an important policy dimension in this regard.

Regarding the social dimension of labor mobility, there is some, although limited, evidence showing that increased mobility may foster socio-cultural integration in Europe and strengthen the European identity (Bonin et al. 2008). Potential drawbacks include social tensions between ethnic minorities and natives. Benton and Petrovic (2013) discuss the impact of migration on local communities and emphasize a need for further research. In particular, the impacts on local communities that are partly overwhelmed with high inflows of migrants are not yet fully understood. While this issue may only affect particular communities and is not representative of the majority of migration flows within the EU, the concern need to be taken seriously and tackled appropriately.

Related to social tensions is the formation of attitudes towards migrants. Careja and Andreß (2013) investigate how national labor market policies shape natives' opinions about immigrants. They find that a more liberal regime with respect to legal aspects of immigrants' access to and security within the labor market leads to more positive opinions about immigrants' economic role in the country. This shows that certain policies are not only able to shape the economic situation of the affected groups, but may also reduce social tensions. Bauer et al. (2000) provide evidence on a similar issue for twelve OECD countries. They find that while natives in countries that receive predominantly refugee migrants are relatively more concerned with the impact of immigration on social issues (e.g., crime), natives in countries that receive predominantly economic migrants are relatively more concerned about losing jobs to immigrants.

In sum, with positive economic gains of increased labor mobility, unclear effects in the social dimension and rather small effects at the demographic level, one can assume that higher labor mobility within Europe would increase welfare for most Europeans (Bonin et al. 2008). 


\subsection{Migration's Drivers and Obstacles}

There are drivers of mobility at the macroeconomic as well as at the individual level. By investigating migration inflows to the EU15, Marques (2010) identifies several factors at the macroeconomic level that increase or decrease migration inflows, corresponding to pull and push factors of migration. Inflows increase due to a higher average income level and a larger size of one's own migrant community in the destination country, as well as the existence of a common language and border. Furthermore, the implementation of liberal immigration policies also contributes to higher inflows. Factors that decrease inflows include a higher unemployment rate in the destination country, a higher average income level and more political freedom in the origin country, as well as a larger distance between origin and destination countries. Palmer and Pytlikova (2013) also look at migration within the EU and find that destinations with easier formal labor market access for migrants have higher immigration rates. Likewise, when competing destinations reduce restrictions to formal labor market access, migration flows to the respective destination country decrease.

Among the microeconomic determinants, certain socio-economic and sociodemographic characteristics are related to higher mobility, such as being younger, male, unmarried and without children, highly educated, unemployed and individuals with migration experience (Bonin et al. 2008). Aparicio Fenoll and Kuehn (2014) find that speaking the language of a country increases the likelihood to migrate to that country by almost five times.

Taking a closer look at survey results of EU migrants who state their main reason for moving, employment proves to be the primary motivation for EU mobility (Benton and Petrovic 2013). This observation differs across countries and includes migrants who move knowing about a prospective job as well as movers without any pre-arranged or planned employment. Family reunification, family formation and accompanying family appear to be the next most important reasons for moving. Other non-negligible reasons are study and retirement. This shows that economic, network, political and individual factors all play a role in determining migration patterns.

Obstacles to European labor mobility have already been discussed in the literature over the last decades (e.g. Zimmermann 1995; Heinz and WardWarmedinger 2006). Among these obstacles, some are related to institutional settings. These include the portability of pension rights or unemployment benefits, transferability of qualifications, inefficient housing markets, disparate education systems and the lack of transparency in job openings. Other barriers are more strongly tied to the individual, such as language and cultural differences. Bonin et al. 
(2008) identify these individual hurdles as more relevant than institutional settings for reducing the propensity to migrate. There is one exception, however, which is the worry about finding a suitable job in the destination area; this is found to be another important mobility deterrent and is related to the institutional setting of transparency and information regarding job openings.

\subsection{The Dual Vocational Training System}

Education and vocational training systems are one institutional factor that either enhances or deters mobility in Europe (Wolter and Ryan 2011). In addition, the dual vocational training system represents a key element of the German model (Baetge and Wolter 2014). In the context of the convergence towards a Single European Labor Market, we thus investigate to what extent other European countries have adopted or should adopt the German system.

The dual vocational training system in Germany is based on four pillars (Eichhorst et al. 2012). First, firm-specific training is provided in centrally accredited occupational qualifications, where the training content is continuously adapted to meet the changing requirements of the labor market. Second, the social partners are involved in developing and maintaining curricula at the governmental and federal level through representative advisory boards. Third, the school-based part of the dual apprenticeships is provided by vocational colleges (Berufsschule) that cover general and occupation-specific education and are government funded. Fourth, firms have to be accredited and must meet certain technical standards before serving as a training firm. Firms themselves must bear the training costs. As apprenticeship contracts are paid below the level of standard contracts, the success of the system critically depends on the trade unions' agreement (Cahuc et al. 2013). These features contribute to a smooth transition from school to work and a relatively low youth unemployment rate (Zimmermann et al. 2013).

A dual vocational training system is also common in Austria, Denmark and Switzerland, and partly in the Netherlands and France (Eichhorst et al. 2012; Wolter and Ryan 2011). In light of very high youth unemployment rates of over 50 percent in some European countries, Germany signed a "Memorandum for the Cooperation in Vocational Education and Training in Europe" with Greece, Italy, Latvia, Portugal, Slovakia and Spain in 2012. The aim is to strengthen cooperation on the modernization of vocational education and training in Europe. Moreover, there were bilateral agreements signed between Germany and Italy, Portugal and Spain to cooperate in the vocational education system, to support those countries in developing a dual vocational education system on their own, and to increase mobility of apprentices. 
However, it does not appear advisable that other countries merely copy the German system, as pointed out by Euler (2013) and Zimmermann et al. (2013). Adapting a vocational training system to a country's needs, structures, institutions and culture represents a more sustainable way of implementing such a new system. What should be established and achieved are common standards to increase mobility in Europe. It is important to have easy and quick recognition of vocational degrees across Europe-not only formally, but firms should also perceive them as relatively similar in terms of degree quality.

\section{IZA Expert Opinion Survey}

In this section, we present unique data from the IZA Expert Opinion Survey on the Single European Labor Market conducted in early 2014. IZA has access to the largest network of labor economists worldwide, comprising more than 1,300 Research Fellows and Policy Fellows from over 45 countries. Among the most prominent IZA Research Fellows are several Nobel laureates. The network of IZA Policy Fellows consists of influential representatives from business, politics, society and the media. All IZA Research Fellows and Policy Fellows based in Europe were approached via email and invited to participate in a short online survey consisting of nine questions. ${ }^{9}$ The purpose of the survey was to get a fresh collection of opinions regarding the current state of the Single European Labor Market, its determinants and the importance of the crisis. As the sample of respondents consists of a representative selection of labor market experts, we can expect highly qualified answers. The individuals were specifically approached as practitioners and experts in labor market issues. However, it should be kept in mind that this selection does not provide an overview of the general public opinion about the Single European Labor Market, labor mobility in the EU, or other European issues.

An email invitation including the survey link was sent to a total of 708 IZA Research Fellows and IZA Policy Fellows that are based in Europe. After two days, those individuals who had not already filled out the questionnaire received a reminder to participate in the survey, and another reminder was sent at a later point in time. In total, 284 individuals (40 percent) completed the questionnaire. Out of these, the largest fractions of respondents are based in Germany (25 percent) and in the United Kingdom (15 percent). About one fifth of the respondents are female and 43 percent rank among the top 12.5 percent of authors according to Research Papers in Economics (RePEc). ${ }^{10}$

\footnotetext{
${ }^{9}$ The questionnaire is included in the Appendix.

${ }^{10}$ See http://www.repec.org; these rankings were accessed in February 2014.
} 


\subsection{The EU and a Single European Labor Market}

In the first part of the survey, we ask the respondents for their general attitudes towards the EU and a Single European Labor Market. Figure 6 shows that more than 60 percent of the respondents claim to be satisfied with the EU, whereas about 30 percent are disappointed. Even though the majority gives a positive answer, one third of labor market experts expressing their frustration about the EU is a rather high share.

Figure 7 shows the distribution of reasons why a Single European Labor Market may be important. Larger economic welfare (almost 70 percent) and greater economic integration (almost 60 percent) rank as the most important. 45 percent of the respondents feel that labor market integration is important for society. Reasons such as political stability, political integration, economic stability and the stability of the Euro are mentioned by around one third of the respondents. There is also a small fraction of respondents ( 5 percent) who believe that a Single European Labor Market is not important. Most respondents (74 percent, depicted in Figure 8) agree that the goal of a Single European Labor Market has not yet been achieved. The picture looks more divided when considering the opinions about whether the state of the Single European Labor Market affects the respondent's satisfaction or disappointment with the EU, as seen in Figure 9. Slightly more than 50 percent expressed that their satisfaction is affected by the state of the single market, whereas 41 percent claim that this is not the case.

Figure 10 shows the distribution of answers to the question about important factors contributing to a Single European Labor Market. Not surprisingly, intra-EU mobility proves to be by far the most important reason, listed by 85 percent of the respondents. Additionally, more than 50 percent name harmonization of social security systems, easy and quick recognition of professional qualifications and a positive attitude towards free mobility by policy makers and by citizens as important for the Single European Labor Market. Moreover, 46 percent claim that the knowledge of several languages is important. Slightly more than one third of the respondents state that the harmonization of labor market policies on the European level and efficient labor market policies on the national level are important. One fourth says that larger cultural integration would be needed, whereas a positive attitude towards the Euro does not appear to be considered an important driver for European labor market integration. In addition, important factors that were mentioned as open answers were the harmonization of fiscal policies, higher mobility also within countries and reduced mobility costs such as information about school and childcare possibilities. 
Figure 11 displays the distribution of the answers to a related question, but now specifically highlighting factors that may enhance labor mobility in Europe. The most frequently stated factor is the easy and quick recognition of professional qualifications. Roughly 70 percent of the respondents name this possibility. The harmonization of social security systems and the knowledge of several languages prove to be almost as important since they are listed by about 60 percent of survey takers. The next important group of factors is policy makers' and citizens' positive attitudes towards mobility. Only one fifth of the respondents believe that enhancing intra-EU mobility of third-country nationals is an important factor to increase intraEU mobility. The harmonization of voting rights does not prove to be important; less than 10 percent stated this as a mobility-enhancing factor. Two reasons that were stated as open answers were again reduced mobility costs, such as information about schools and childcare facilities, as well as the integration of school systems.

\subsection{The Great Recession and the Role of Reforms}

Additional questions concern the Great Recession and the importance of reforms for dealing with it. Figure 12 shows that the majority of the respondents-about 60 percent-believe the economic divergence between EU member states after the crisis will last a long time. Only one quarter of the respondents think that this is a rather transitional phenomenon.

Figures 13 and 14 display the results to the question of whether or not respondents believe that economic and labor reform policies are important to deal with this divergence after the crisis, responding for both their own country and Europe in general. Three patterns emerge from these figures. First, a clear majority (ranging between 67 and 89 percent) thinks that reforms are important to deal with this divergence. Second, economic reform policies are considered as slightly more important than labor reform policies. Third, reforms on the European level prove to be of greater importance than on the individual country level.

\subsection{Summary of Descriptive Evidence}

The descriptive analysis of the survey shows the following important results: A clear majority of labor market experts believes that a Single European Labor Market is important, mainly for overall economic welfare. However, the majority is also convinced that Europe has not yet achieved this goal. About half of the respondents claim that their attitude towards the EU is affected by the progress of the Single European Labor Market. Intra-EU labor mobility proves to be the most important factor to achieve a single market. The recognition of professional qualifications, the harmonization of social security systems and the knowledge of several languages are identified as the key factors to enhance labor mobility across Europe. Most 
respondents believe that the increasing divergence due to the crisis represents a long-lasting phenomenon. Moreover, the majority thinks that particularly economic reforms, but also labor market reforms, are important to deal with this situation, especially at the European level.

In sum, it appears that further measures to achieve the Single European Labor Market are desired and necessary. Even though the crisis has created tensions between European countries (Zahn 2013), policy makers are generally trusted to be able to deal with these issues.

\subsection{Regression Analysis}

What background characteristics of the respondents are related to the different answers on certain survey questions? Table 1 displays the results of a regression analysis. More specifically, it shows the average marginal effects of probit regressions on the answers to four different survey questions. Each question has two different regression specifications in two different columns that involve different country group dummies (country of origin vs. country of residence).

First, we analyze the question whether the respondents are satisfied with the EU in columns (1) and (2). The dummy outcome variable indicates that a person is satisfied. Accordingly, female respondents and migration researchers are significantly more likely to be satisfied with the EU. To some extent, this also holds for researchers from top-level institutions.

Second, we analyze the question whether the respondents agree that the goal of a Single European Labor Market is largely achieved in columns (3) and (4). The dummy outcome variable indicates agreement. Marginal effects indicate that researchers whose home country is one of the crisis countries (Greece, Ireland, Italy, Portugal or Spain) are significantly less likely to agree with that statement. In contrast, researchers who reside in Germany are significantly more likely to agree. Lastly, researchers who completed their PhD degree outside their home country are to some extent less likely to agree.

Third, we analyze the question whether the respondents' satisfaction or disappointment with the EU is affected by the state of the integration of the European labor markets in columns (5) and (6). The dummy outcome variable indicates that their (dis-)satisfaction is affected by this issue. Accordingly, top researchers are significantly less likely to be affected in their satisfaction or disappointment than other researchers. ${ }^{11}$ This is also the case for researchers who

\footnotetext{
${ }^{11}$ In this context, top researchers are those who rank among the top 12.5 percent of authors according to Research Papers in Economics (RePEc), and those who have published at least one article in an $\mathrm{A} / \mathrm{A}+$ journal.
} 
come from or reside in Eastern Europe or in Germany, and for researchers residing in Central Europe.

Fourth, we analyze the question whether the divergence created by the economic crisis represents a long-lasting phenomenon in columns (7) and (8). The dummy outcome variable indicates that respondents think that it is a long-lasting phenomenon. Migration researchers are significantly less likely to agree to this statement, thus are more likely to regard it as a transitional phenomenon. Researchers from crisis countries and from Central Europe, on the other hand, are significantly more likely to regard the divergence as a long-lasting phenomenon.

Hence, the impact of the economic crisis in specific countries seems to influence the perception of the state of a Single European Labor Market. Furthermore, migration researchers seem to be more prone to the idea of mobility as an adjustment mechanism.

\section{Conclusions}

Labor mobility across Europe is not a new subject. The first legal attempts for the free movement of workers were established in the 1950s. While a Single European Labor Market may create certain drawbacks, it certainly entails benefits that are likely to outweigh the downsides. Labor market experts agree that free labor mobility is important for overall economic welfare, economic integration and society. However, there is also wide agreement among academics and policy makers that a Single European Labor Market has not yet been achieved. In other words, mobility within Europe is not high enough to fully induce the related benefits. Obstacles to free mobility include language and cultural differences, the monetary costs of moving, inefficient housing markets, the lack of harmonization of social security benefits, insufficient international recognition of professional qualifications, disparate education systems and the lack of transparency in job openings. Although low net migration does not necessarily imply that a Single European Labor Market is not functioning, relatively high mobility rates indeed appear as a necessary condition to achieve a Single European Labor Market.

Sensible policy recommendations mainly tackle institutional measures such as a more appropriate use of tools like EURES, in order to increase the distribution of information about jobs across Europe, ${ }^{12}$ simplifying the recognition of professional qualifications and harmonizing social security systems, such as the pension and unemployment systems as well as harmonizing education and vocational training systems (see also Dhéret et al. 2013). On the other hand, attitudes regarding the EU

12 For more information on EURES, the European job mobility portal, see https://ec.europa.eu/eures/. 
and free mobility should not be overlooked while moving towards a Single European Labor Market: At least 50 percent of labor market experts in the IZA Expert Opinion Survey consider positive attitudes-by policy makers and citizens alike-towards free mobility to be important to enhance labor mobility. Furthermore, recent developments in Europe, such as a joint letter by ministers of four member states to the European Council emphasizing the threat of welfare migration, as well as a referendum in Switzerland in favor of reintroducing immigration quotas, are very likely to create anti-immigration sentiments within Europe. These evolutions need to be taken seriously and taken into account when creating policy recommendations. For example, labor market policies and work-related migration regulations may influence natives' opinions about immigrants and attitudes towards immigration.

A Single European Labor Market has not been accomplished yet. This is the clear message from the IZA Expert Opinion Survey 2014. However, do we observe patterns of convergence? To some extent, this is the case. For example, Germany currently serves simultaneously as a role model and as a copy-cat country. A prime example for the former is the country's vocational education system, and for the latter the introduction of a statutory minimum wage. If such a process continued and mobility increased, Europe could converge towards a Single European Labor Market.

\section{Acknowledgements}

We would like to thank Margard Ody, Nikos Askitas, Timo Baas, Victoria Finn, the Editor, two anonymous referees, and participants at the IAB Workshop "The Transformation of the German Model" in Nuremberg for helpful support and valuable comments on earlier versions of this paper. All remaining errors are our own.

\section{References}

Altonji, J.G., Card, D.: The Effects of Immigration on the Labor Market Outcomes of LessSkilled Natives. In Abowd, J.M., Freeman, R.B. (Eds.) Immigration, Trade and the Labor Market, pp. 201-234. University of Chicago Press, Chicago (1991)

Aparicio Fenoll, A., Kuehn, Z.: Does Foreign Language Proficiency Foster Migration of Young Individuals within the European Union? IZA Discussion Paper No. 8250, Institute for the Study of Labor (IZA), Bonn (2014)

Baetge, M., Wolter, A.: The German Skill Formation Model in Transition: From dual VETsystem to a Higher Education Model, J. Labour Market Res. (this issue, 2014)

Bauer, T.K., Lofstrom, M., Zimmermann, K.F.: Immigration Policy, Assimilation of Immigrants, and Natives' Sentiments Towards Immigrants: Evidence from 12 OECD Countries, Swedish Economic Policy Review 7, 11-53 (2000)

Benton, M., Petrovic, M.: How Free Is Free Movement? Dynamics and Drivers of Mobility within the European Union. MPI Report, Migration Policy Institute Europe, Brussels (2013) 
Bertoli, S., Brücker, H., Fernández-Huertas Moraga, J.: The European Crisis and Migration to Germany: Expectations and the Diversion of Migration Flows. IZA Discussion Paper No. 7170, Institute for the Study of Labor (IZA), Bonn (2013)

Biavaschi, C., Zimmermann, K.F.: Eastern Partnership Migrants in Germany: Outcomes, Potentials and Challenges. IZA Journal of European Labor Studies 3:7 (2014). Doi: 10.1186/2193-9012-3-7

Bonin, H.: Wage and Employment Effects of Immigration to Germany: Evidence from a Skill Group Approach. IZA Discussion Paper No. 1875, Institute for the Study of Labor (IZA), Bonn (2005)

Bonin, H., Eichhorst, W., Florman, C., Hansen, M.O., Skiöld, L., Stuhler, J., Tatsiramos, K., Thomasen, H., Zimmermann, K.F.: Geographic Mobility in the European Union: Optimising its Economic and Social Benefits. IZA Research Report No. 19, Institute for the Study of Labor (IZA), Bonn (2008)

Borjas, G.J: Economic Theory and International Migration. International Migration Review, 23, 457-485 (1989)

Brenke, K.: Labor Mobility in Central and Eastern Europe: The Migration of Workers to Germany Has Been Limited in Scope. DIW Econ. Bull. 1, 10-24 (2011)

Brunow, S., Brenzel, H.: The Effect of a Culturally Diverse Labour Supply on Regional Income in the EU. Empirica. 39, 461-485 (2012)

Careja, R., Andreß, H.J.: Needed but Not Liked - The Impact of Labor Market Policies on Natives' Opinions about Immigrants. Int. Migr. Rev. 47, 374-413 (2013)

Constant, A.F, Zimmermann, K.F.: Migration and ethnicity: an introduction. In: Constant, A.F., Zimmermann, K.F. (Eds.), International Handbook on the Economics of Migration, pp. 13-35. Edward Elgar Publishing, Cheltenham, UK, and Northampton, USA (2013)

Dhéret, C., Lazarowicz, A., Nicoli, F., Pascouau, Y., Zuleeg, F.: Making progress towards the completion of the Single European Labour Market. EPC Issue Paper No. 75, European Policy Centre (EPC), Brussels (2013)

Eichhorst W., Rodríguez-Planas, N., Schmidl, R., Zimmermann, K.F.: A Roadmap to Vocational Education and Training Systems around the World. IZA Discussion Paper No. 7110, Institute for the Study of Labor (IZA), Bonn (2012)

Elsner, B.: Does emigration benefit the stayers? Evidence from EU enlargement, Journal of Population Economics 26, 531-553 (2013)

Euler, D.: Germany's Dual Vocational Training System: a Model for Other Countries? Study commissioned by the Bertelsmann Stiftung, Gütersloh (2013)

European Commission: Single Market Act II-Together for New Growth. Communication from the Commission to the European Parliament, the Council, the European Economic and Social Committee and the Committee of the Regions, COM 573 final (2012)

Galgoczi, B., Leschke, J.: Intra-EU Labour Migration after Eastern Enlargement and During the Crisis. ETUI Working Paper 2012.13, European Trade Union Institute (ETUI), Brussels (2012)

Giulietti, C., Wahba, J.: Welfare Migration. In: Constant, A.F., Zimmermann, K.F. (Eds.), International Handbook on the Economics of Migration, pp. 489-504. Edward Elgar Publishing, Cheltenham, UK, and Northampton, USA (2013)

Heinz, F.F., Ward-Warmedinger, M.: Cross-Border Labour Mobility within an Enlarged EU. ECB Occasional Paper Series No. 52, European Central Bank (ECB), Frankfurt (2006)

Jauer, J., Liebig, T., Martin, J.P., Puhani, P.A.: Migration as an Adjustment Mechanism in the Crisis? A Comparison of Europe and the United States. IZA Discussion Paper No. 7921, Institute for the Study of Labor (IZA), Bonn (2014)

Kahanec, M.: Labor Mobility in an Enlarged European Union. In: Constant, A.F., Zimmermann, K.F. (Eds.), International Handbook on the Economics of Migration, pp. 137-152. Edward Elgar Publishing, Cheltenham, UK, and Northampton, USA (2013) 
Kahanec, M., Zimmermann, K.F.: EU Labor Markets After Post-Enlargement Migration. Springer, Berlin (2009)

Marques, H.: Migration Creation and Diversion in the European Union: Is Central and Eastern Europe a 'Natural' Member of the Single Market for Labour? J. Common Mark. Stud. 48, 265-291 (2010)

Mundell, R.A.: A Theory of Optimum Currency Areas, American Economic Review 51(4), 657665 (1961)

Palmer, J., Pytlikova, M.: Labor Market Laws and Intra-European Migration. The Role of the State in Shaping Destination Choices. CELSI Discussion Paper No. 9, Central European Labour Studies Institute (CELSI), Bratislava (2013)

Parrotta, P., Pozzoli, D., Pytlikova, M.: The Nexus Between Labor Diversity and Firm's Innovation, Journal of Population Economics 27, 303-364 (2014)

Piracha, M., Tani, M., Vadean, F.: Immigrant Over- and Under-education: The Role of Home Country Labour Market Experience. IZA Journal of Migration 1:3 (2012). doi: 10.1186/2193-9039-1-3

Piracha, M., Vadean, F.: Migrant Educational Mismatch and the Labor Market. In: Constant, A.F., Zimmermann, K.F. (Eds.), International Handbook on the Economics of Migration, pp. 176 - 192. Edward Elgar Publishing, Cheltenham, UK, and Northampton, USA (2013)

Rinne, U., Zimmermann, K.F.: Another Economic Miracle? The German Labor Market and the Great Recession. IZA J. Labor Policy. 1:3 (2012). doi: 10.1186/2193-9004-1-3

Rinne, U., Zimmermann, K.F.: Is Germany the North Star of Labor Market Policy? IMF Economic Review 61(4), 702-729 (2013)

Ritzen, J., Zimmermann, K.F.: A Vibrant European Labor Market with Full Employment. IZA Journal of European Labor Studies, 3:10 (2014). doi: 10.1186/2193-9012-3-10

Ritzen, J., Zimmermann, K.F., Wehner, C.: Euroscepticism in the Crisis: More Mood than Economy. IZA Discussion Paper No. 8001, , Institute for the Study of Labor (IZA), Bonn (2014)

Sjaastad, L.A.: The Costs and Returns of Human Migration. J. Polit. Econ. 70, 80-89 (1962)

Vitols, S.: Globalization and the Transformation of the German Model. In: Underhill, G.R.D. (Ed.), Political Economy and the Changing Global Order, 3rd Edition, 398-407. Oxford University Press, Oxford (2005)

Vliet, O. van, Koster, F.: Europeanisation and the Political Economy of Active Labour Market Policies. Eur. Union Polit. 12, 217-239 (2011)

Wolter, S., and P. Ryan. "Apprenticeship." In: Hanushek, E., S. Machin, and L. Woessmann (eds).Economics of Education. Volume 3. Handbooks in Economics, 521-576. NorthHolland, Amsterdam (2011)

Zahn, R.: European Enlargement and the Economic Crisis: Impact and Lasting Effects. ETUI Working Paper 2013.01, European Trade Union Institute (ETUI), Brussels (2013)

Zimmermann, K.F.: Tackling the European Migration Problem. J. Econ. Perspect. 9, 45-62 (1995)

Zimmermann, K.F.: European Labour Mobility: Challenges and Potentials. De Econ. 153, 425450 (2005)

Zimmermann, K.F.: The Mobility Challenge for Growth and Integration in Europe. IZA Policy Paper No. 69, Institute for the Study of Labor (IZA), Bonn (2013a)

Zimmermann, K.F.: Labor Market Reforms and the Great Recession, IZA Policy Paper No. 75, Institute for the Study of Labor (IZA), Bonn (2013b)

Zimmermann, K.F., Biavaschi, C., Eichhorst, W., Giulietti, C., Kendzia, M.J., Muravyev, A., Pieters, J., Rodríguez-Planas, N., Schmidl, R.: Youth Unemployment and Vocational Training, Found. Trends. Micro. 9, 1-157 (2013) 
Figure 1: GDP

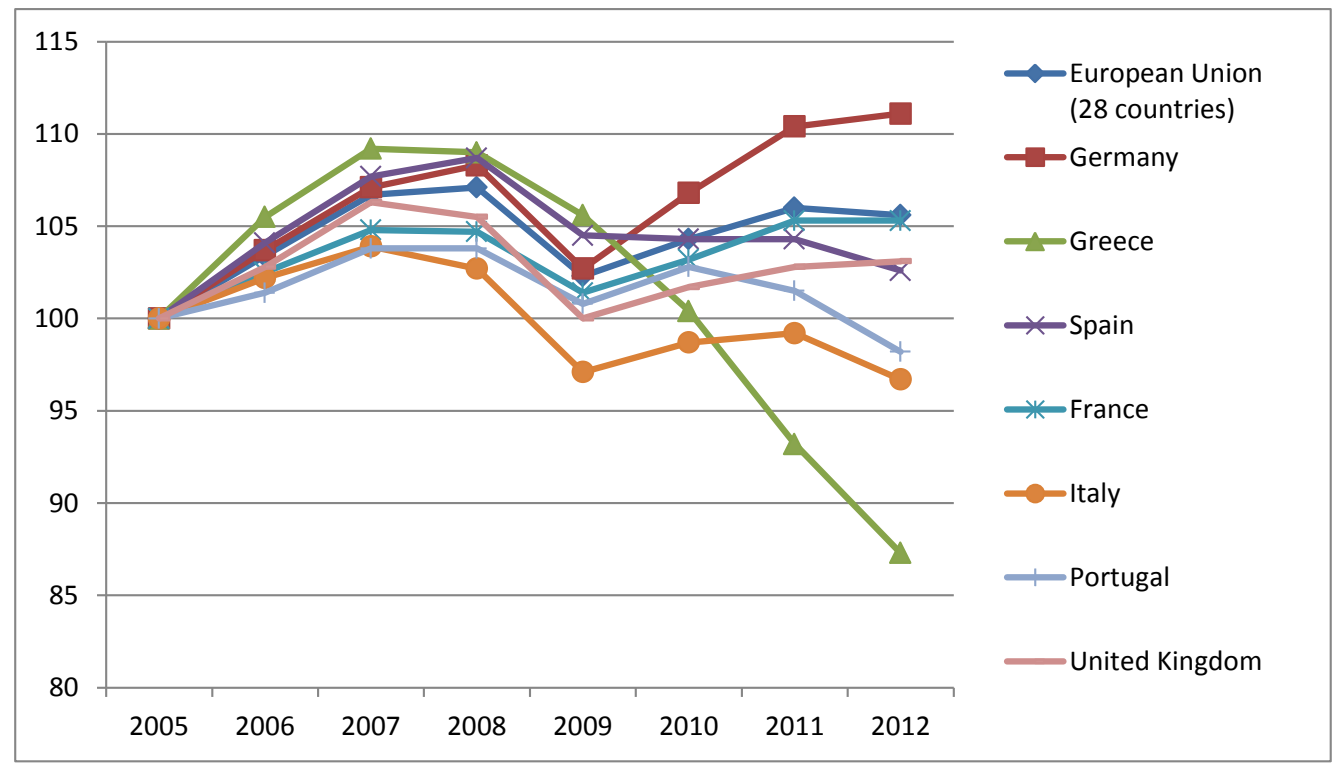

Source: Eurostat.

Notes: Gross domestic product (GDP) at market prices in millions of euro; 2005=100.

\section{Figure 2: Gini Coefficient}

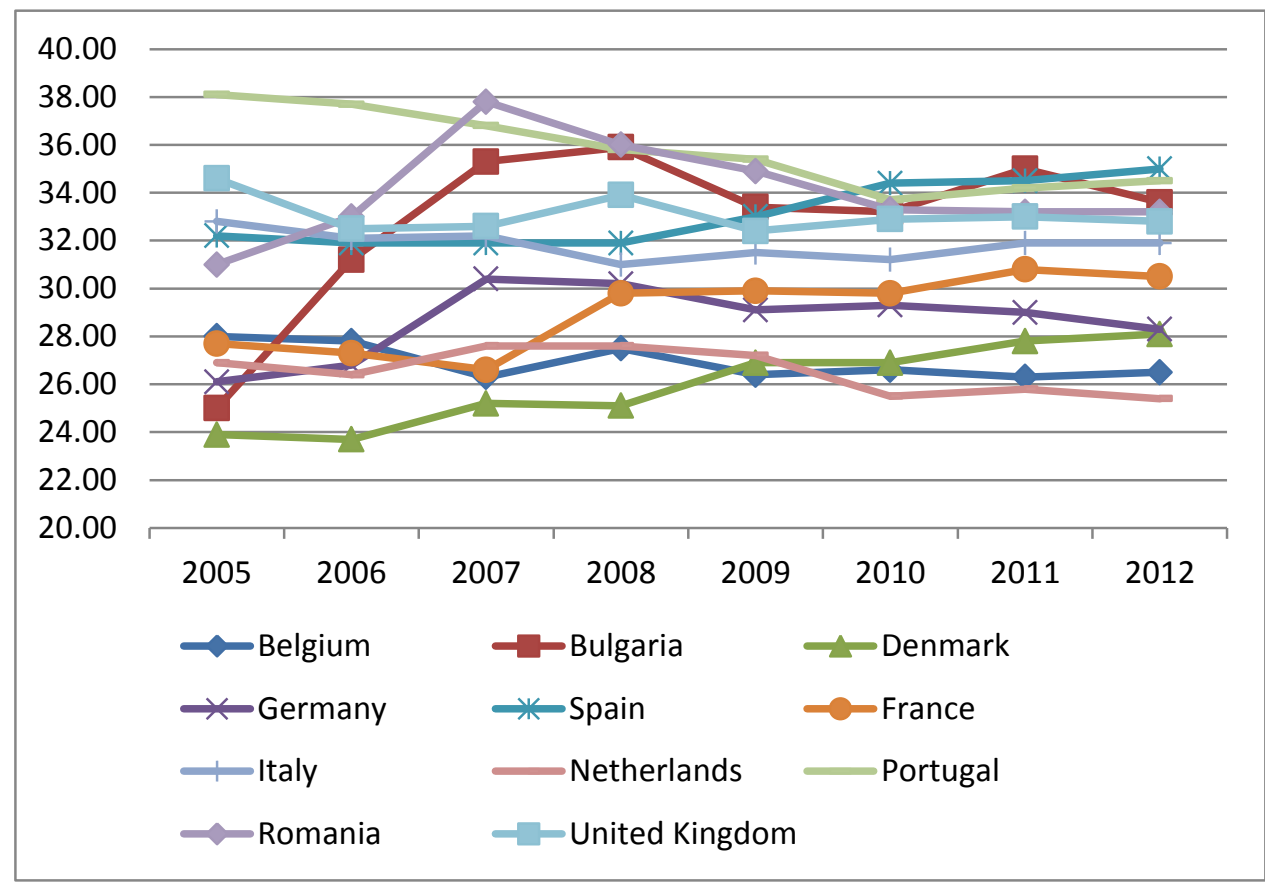

Source: Eurostat. 
Figure 3: Unemployment Rate

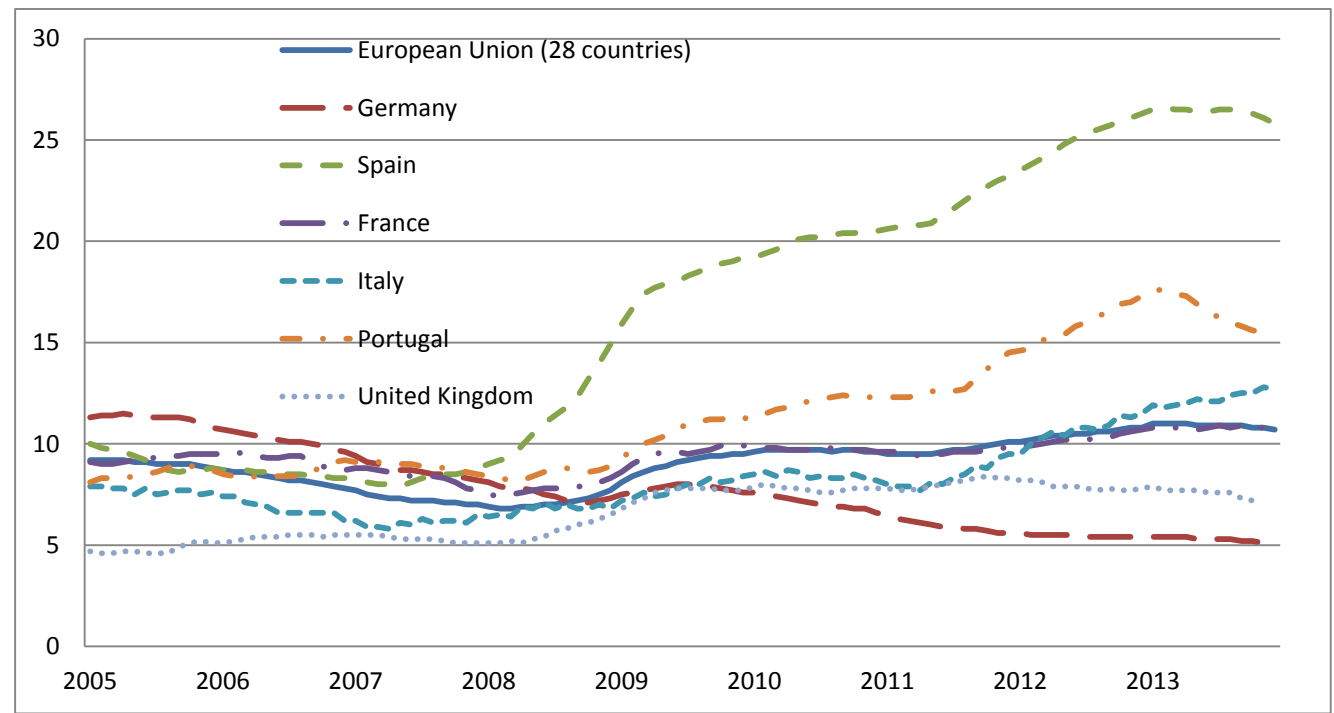

Source: Eurostat.

Note: Seasonally adjusted monthly unemployment rates in percent.

Figure 4: Net Migration of EU27 to Selected Countries

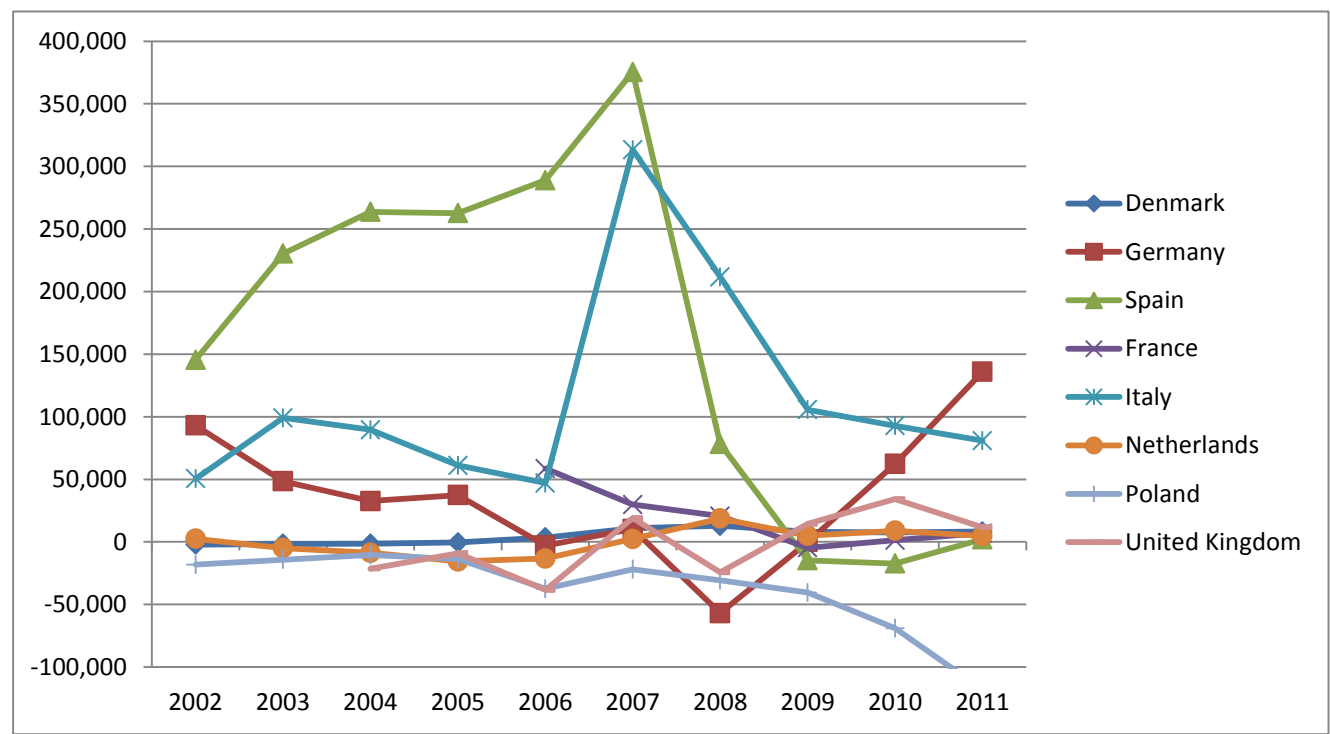

Source: Eurostat; own calculations.

Notes: Net migration rates are calculated as the difference between immigration and emigration rates for a given country in a given year. Immigration rates include inflows from EU27 nationals, while emigration rates include outflows of EU27 nationals to other destination countries. 
Figure 5: Labor Market Policies Expenditure as Percentage of GDP

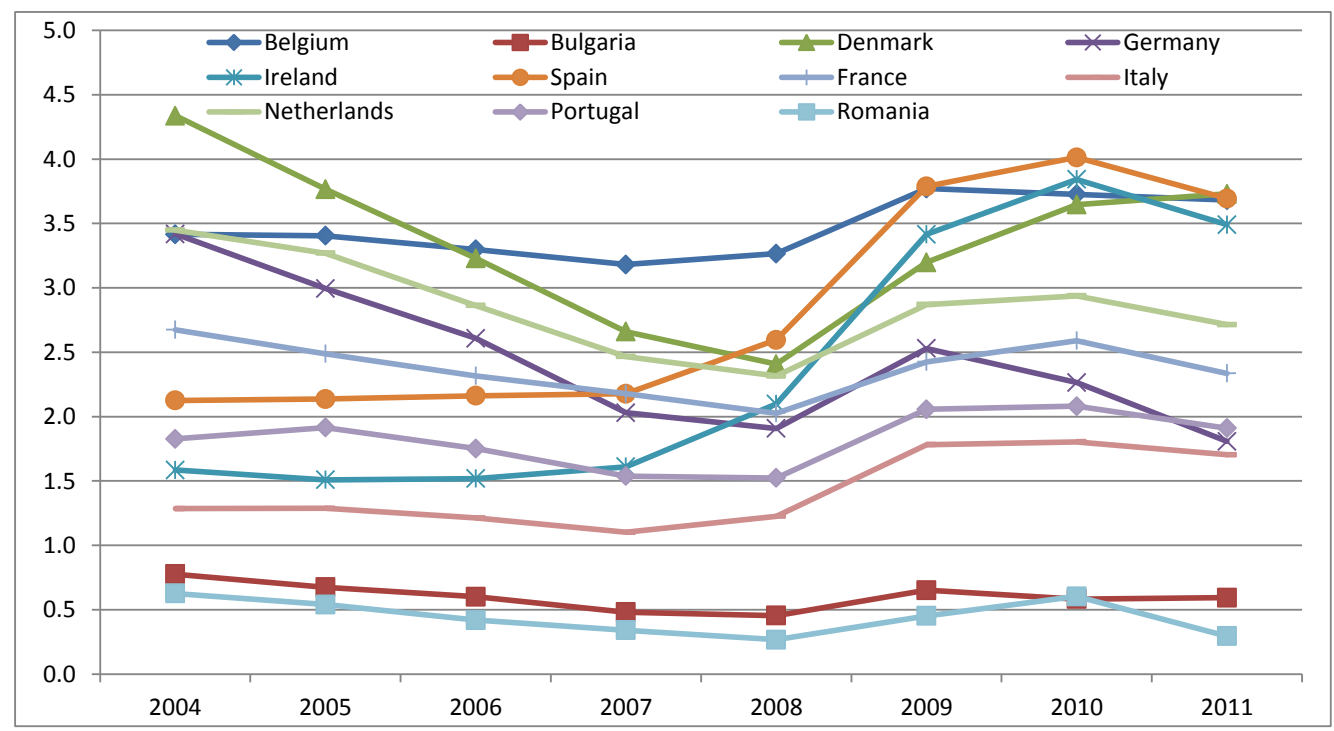

Source: Eurostat.

Note: Expenditure for all types of labor market policies.

Figure 6: Satisfaction with the EU

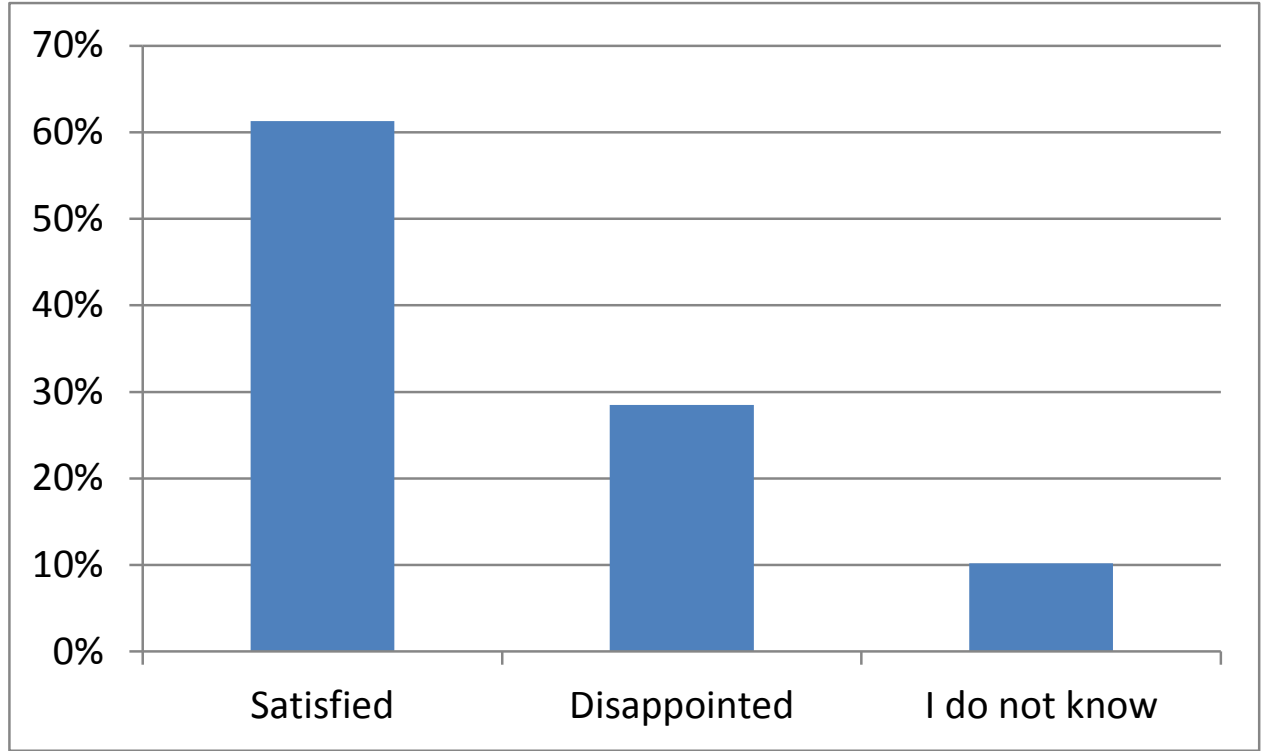

Source: IZA Expert Opinion Survey 2014.

Note: Number of observations: 284. 
Figure 7: Importance of a Single European Labor Market for...

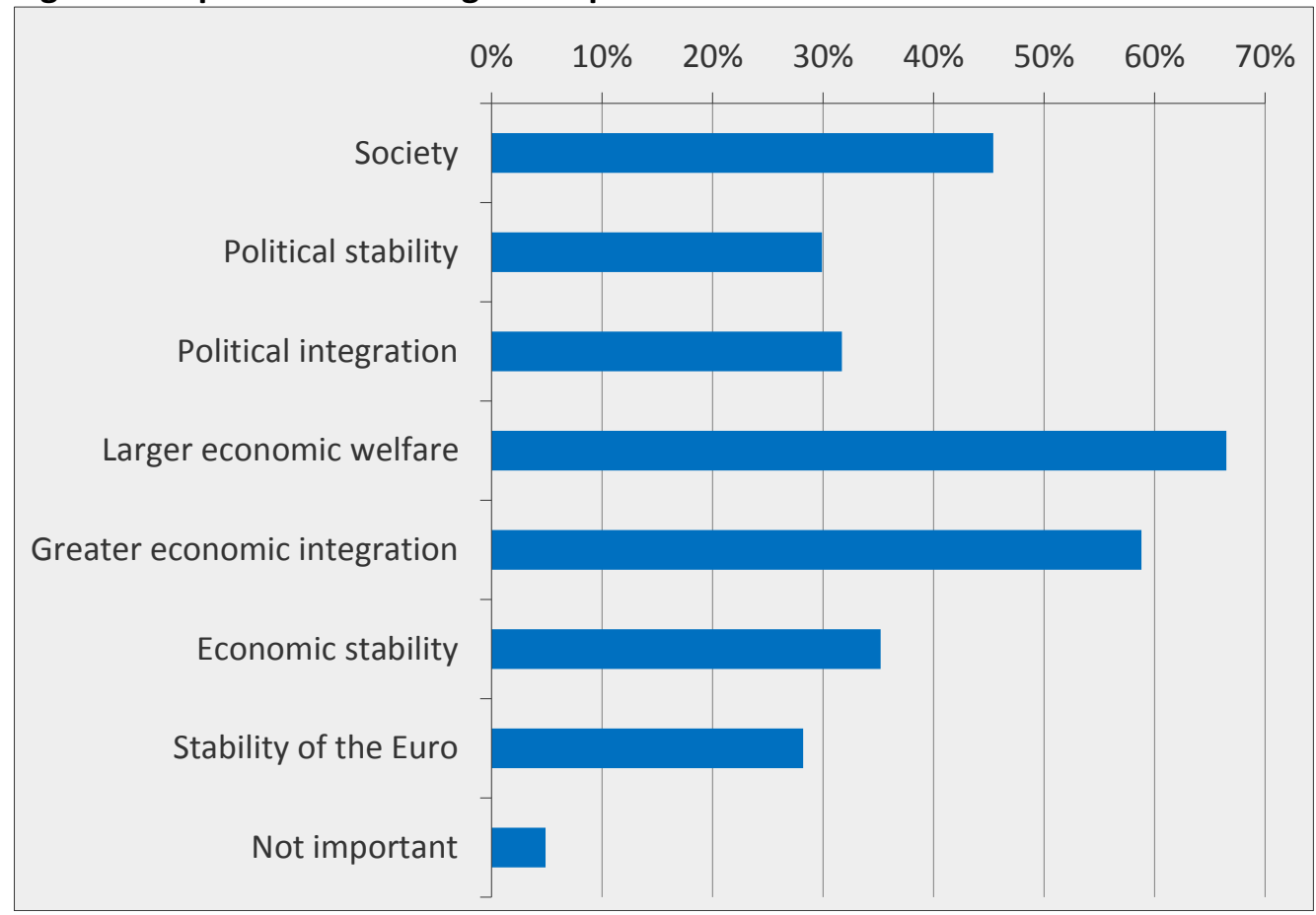

Source: IZA Expert Opinion Survey 2014.

Notes: Number of observations: 284 (14 observations refer to "I don't know" and "Other, please specify"); several answers possible.

Figure 8: "The Single European Labor Market is largely achieved."

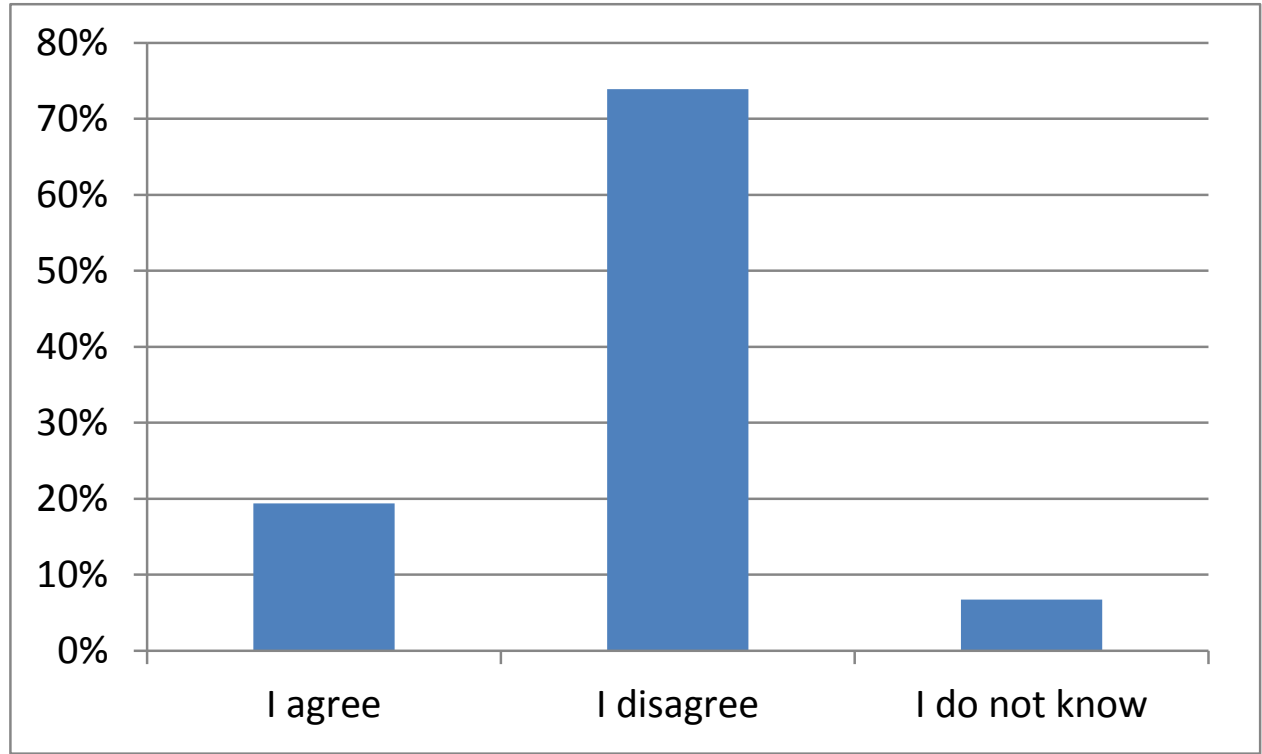

Source: IZA Expert Opinion Survey 2014.

Note: Number of observations: 284. 
Figure 9: "Satisfaction with the EU is affected by the states of the integration of European Labor Markets."

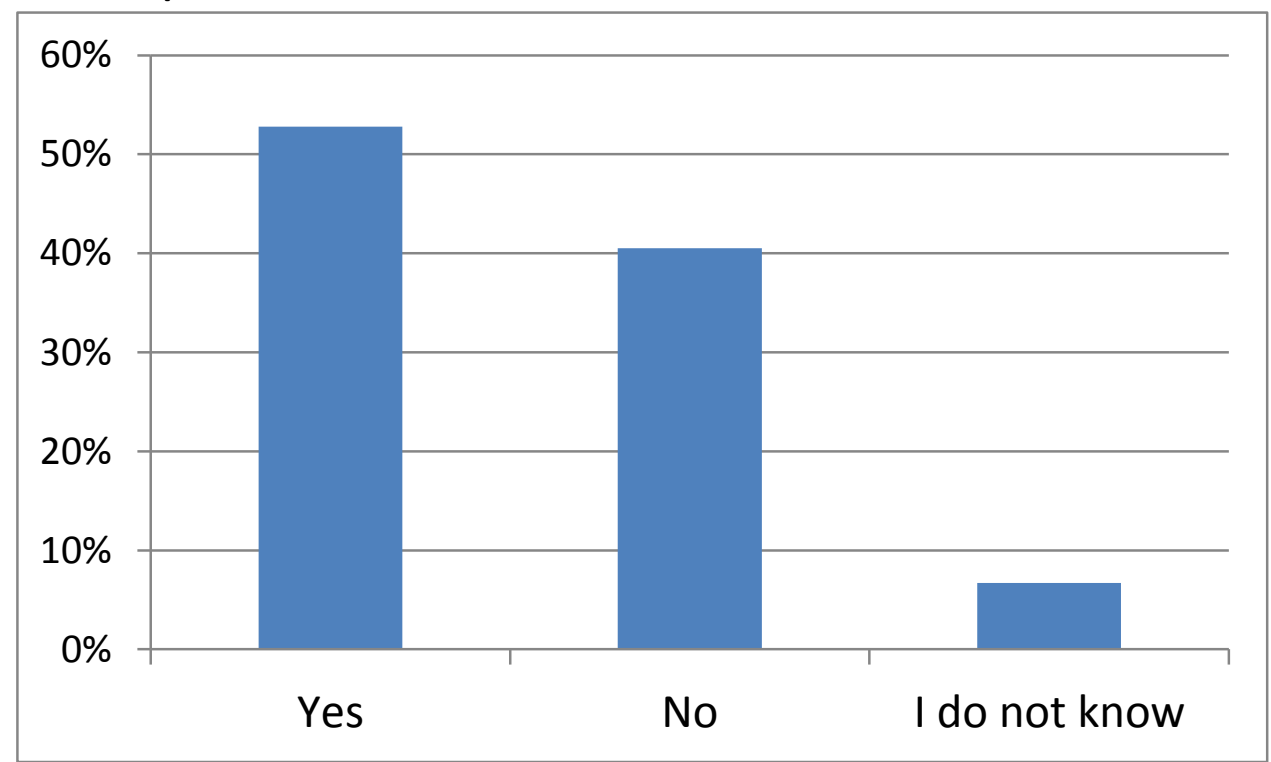

Source: IZA Expert Opinion Survey 2014.

Note: Number of observations: 284.

\section{Figure 10: Essential Factors for a Single European Labor Market}

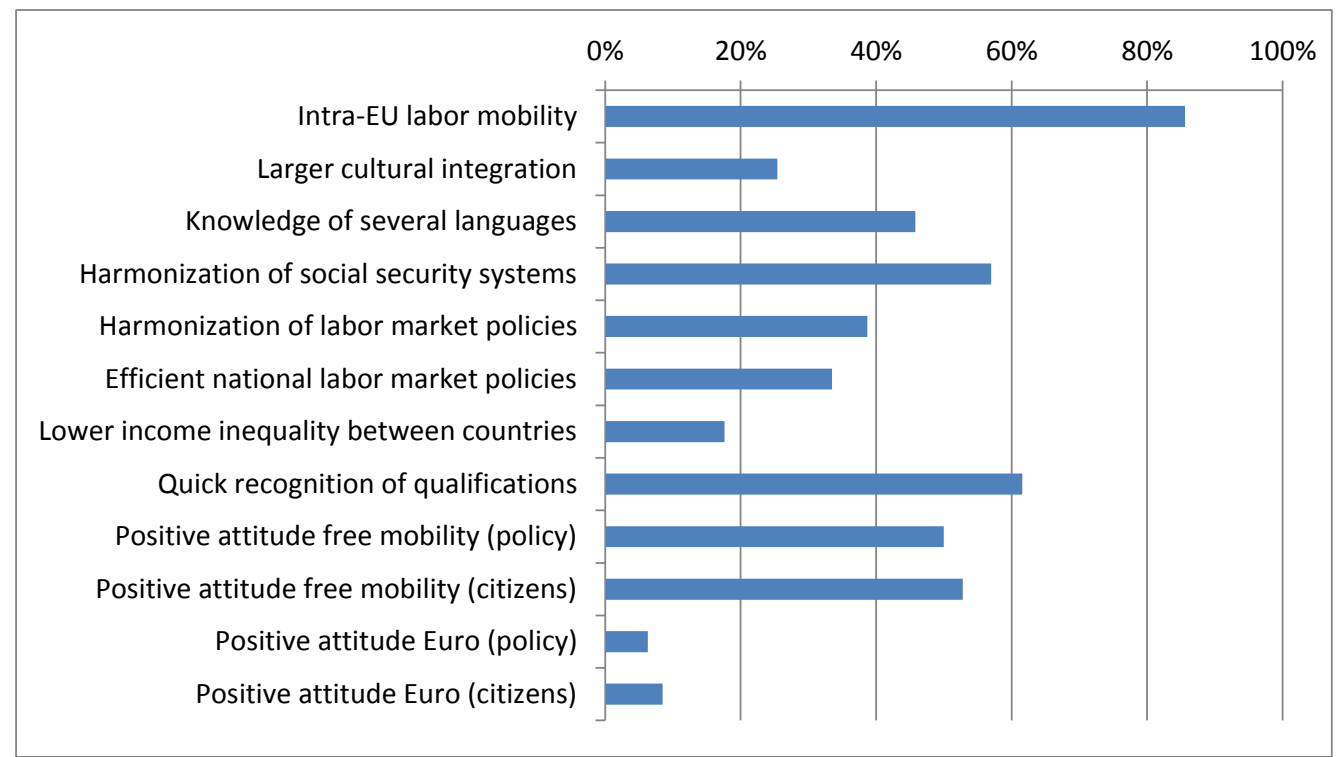

Source: IZA Expert Opinion Survey 2014.

Notes: Number of observations: 284 (19 observations refer to "Other, please specify"); several answers possible. 
Figure 11: Factors to Enhance Labor Mobility across Europe

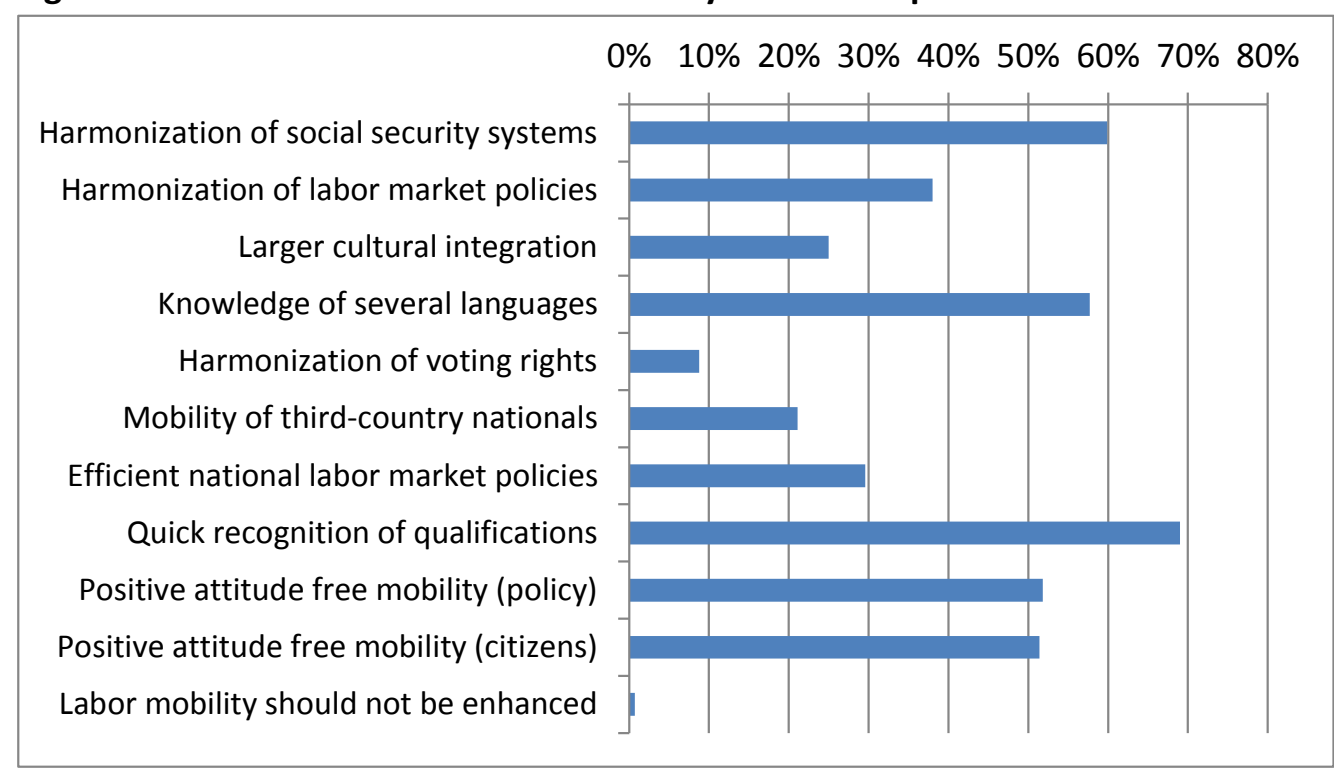

Source: IZA Expert Opinion Survey 2014.

Notes: Number of observations: 284 (11 observations refer to "I don't know" and "Other, please specify"); several answers possible.

\section{Figure 12: Long-lasting Divergence after the Crisis?}

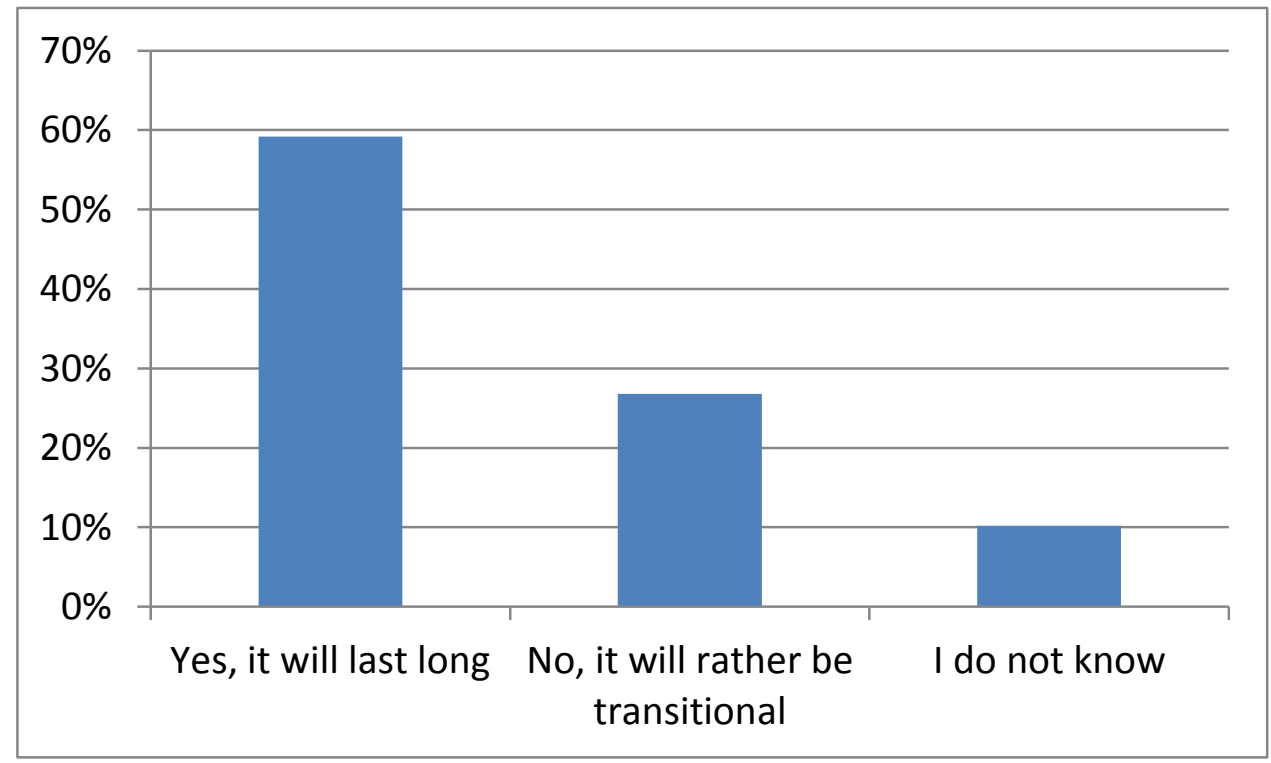

Source: IZA Expert Opinion Survey 2014.

Note: Number of observations: 284 (11 observations refer to "Other, please specify"). 
Figure 13: Importance of Reform Policies to Deal with the Crisis-in my Country

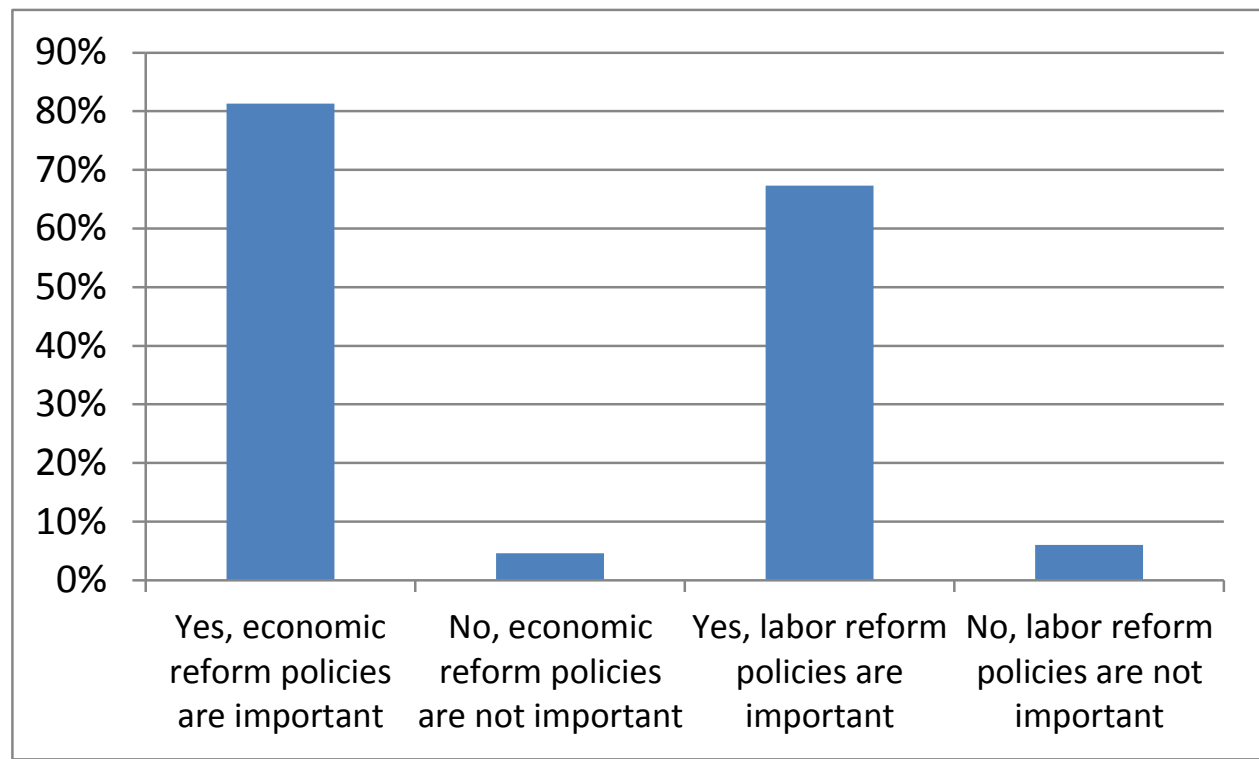

Source: IZA Expert Opinion Survey 2014.

Note: Number of observations: 284 (23 observations refer to "I don't know" and "Other, please specify").

\section{Figure 14: Importance of Reform Policies-in General in the EU}

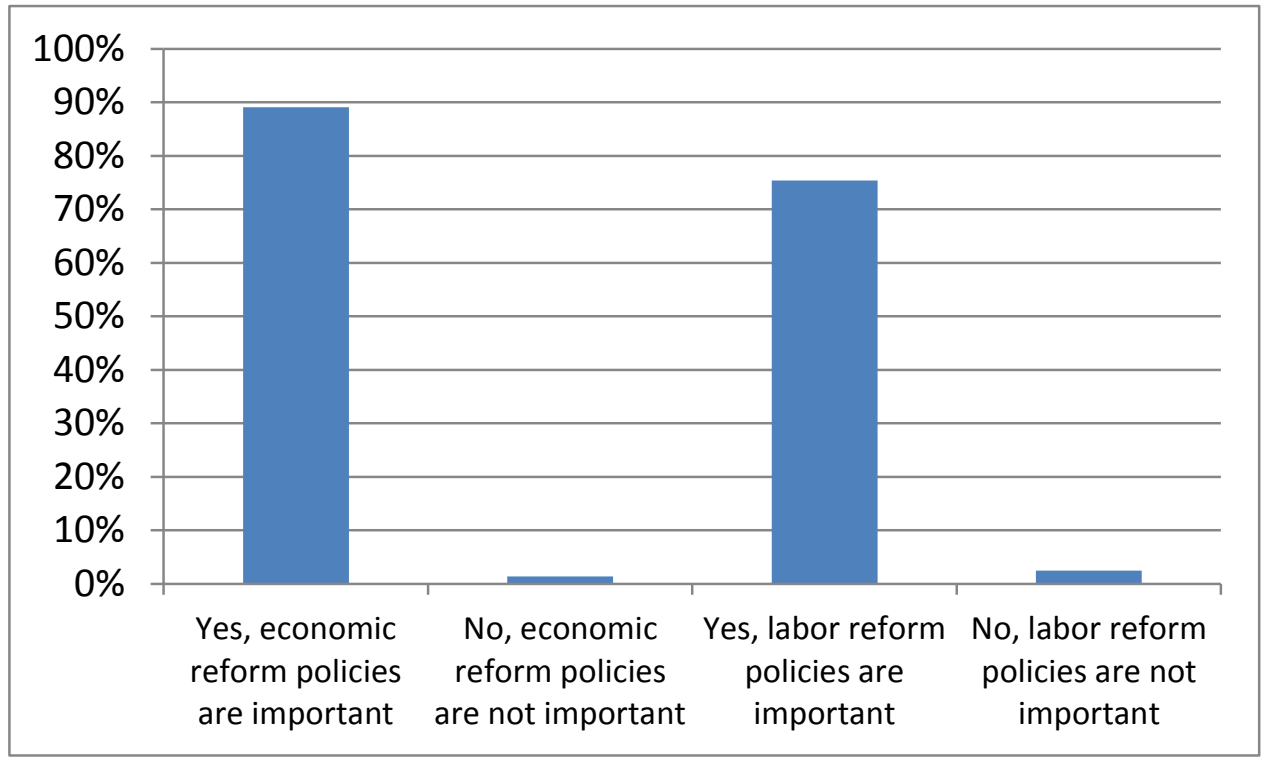

Source: IZA Expert Opinion Survey 2014.

Note: Number of observations: 284 (21 observations refer to "I don't know" and "Other, please specify"). 
Table 1: Probit Regressions

\begin{tabular}{|c|c|c|c|c|c|c|c|c|}
\hline \multirow{3}{*}{ Female } & (1) & $(2)$ & (3) & (4) & (5) & (6) & (7) & (8) \\
\hline & \multicolumn{2}{|c|}{$\begin{array}{l}\text { Satisfaction } \\
\text { with the } \mathrm{EU}^{\mathrm{a}}\end{array}$} & \multicolumn{2}{|c|}{$\begin{array}{c}\text { Single Market largely } \\
\text { achieved }^{\mathrm{b}}\end{array}$} & \multicolumn{2}{|c|}{$\begin{array}{l}\text { EU-Satisf. affected by } \\
\text { Single Market }{ }^{c}\end{array}$} & \multicolumn{2}{|c|}{$\begin{array}{l}\text { Divergence long- } \\
\text { lasting Phenomenon }\end{array}$} \\
\hline & $\begin{array}{c}0.212^{* * *} \\
(0.071)\end{array}$ & $\begin{array}{l}0.184^{* *} \\
(0.074)\end{array}$ & $\begin{array}{l}-0.015 \\
(0.066)\end{array}$ & $\begin{array}{l}-0.053 \\
(0.066)\end{array}$ & $\begin{array}{l}-0.024 \\
(0.077)\end{array}$ & $\begin{array}{l}-0.042 \\
(0.079)\end{array}$ & $\begin{array}{c}0.044 \\
(0.078)\end{array}$ & $\begin{array}{c}0.046 \\
(0.082)\end{array}$ \\
\hline Lives outside home country & $\begin{array}{l}-0.035 \\
(0.077)\end{array}$ & $\begin{array}{l}-0.006 \\
(0.080)\end{array}$ & $\begin{array}{l}-0.048 \\
(0.068)\end{array}$ & $\begin{array}{c}0.015 \\
(0.066)\end{array}$ & $\begin{array}{c}0.074 \\
(0.077)\end{array}$ & $\begin{array}{c}0.054 \\
(0.083)\end{array}$ & $\begin{array}{l}-0.050 \\
(0.077)\end{array}$ & $\begin{array}{c}0.006 \\
(0.080)\end{array}$ \\
\hline PhD studies not in home country & $\begin{array}{c}0.088 \\
(0.064)\end{array}$ & $\begin{array}{c}0.067 \\
(0.065)\end{array}$ & $\begin{array}{l}-0.077 \\
(0.055)\end{array}$ & $\begin{array}{l}-0.100^{*} \\
(0.055)\end{array}$ & $\begin{array}{c}0.036 \\
(0.071)\end{array}$ & $\begin{array}{c}0.009 \\
(0.073)\end{array}$ & $\begin{array}{l}-0.040 \\
(0.070)\end{array}$ & $\begin{array}{l}-0.047 \\
(0.071)\end{array}$ \\
\hline At least 1 paper in $A / A+$ journal $^{e}$ & $\begin{array}{l}-0.051 \\
(0.066)\end{array}$ & $\begin{array}{l}-0.042 \\
(0.067)\end{array}$ & $\begin{array}{c}0.035 \\
(0.058)\end{array}$ & $\begin{array}{c}0.057 \\
(0.058)\end{array}$ & $\begin{array}{c}-0.163^{* *} \\
(0.068)\end{array}$ & $\begin{array}{l}-0.113 \\
(0.069)\end{array}$ & $\begin{array}{c}0.051 \\
(0.069)\end{array}$ & $\begin{array}{c}0.048 \\
(0.070)\end{array}$ \\
\hline Top author in Europe ${ }^{f}$ & $\begin{array}{l}-0.029 \\
(0.069)\end{array}$ & $\begin{array}{l}-0.039 \\
(0.067)\end{array}$ & $\begin{array}{c}0.026 \\
(0.057)\end{array}$ & $\begin{array}{l}0.004 \\
(0.057)\end{array}$ & $\begin{array}{c}-0.156 * * \\
(0.071)\end{array}$ & $\begin{array}{c}-0.146 * * \\
(0.068)\end{array}$ & $\begin{array}{c}0.007 \\
(0.071)\end{array}$ & $\begin{array}{l}-0.000 \\
(0.070)\end{array}$ \\
\hline Migration research interest & $\begin{array}{c}0.146^{* *} \\
(0.067)\end{array}$ & $\begin{array}{c}0.141^{* *} \\
(0.067)\end{array}$ & $\begin{array}{c}0.025 \\
(0.056)\end{array}$ & $\begin{array}{l}0.028 \\
(0.055)\end{array}$ & $\begin{array}{l}-0.055 \\
(0.068)\end{array}$ & $\begin{array}{c}-0.041 \\
(0.069)\end{array}$ & $\begin{array}{c}-0.142 * * \\
(0.067)\end{array}$ & $\begin{array}{c}-0.152^{* *} \\
(0.066)\end{array}$ \\
\hline Top level institution ${ }^{\mathrm{g}}$ & $\begin{array}{l}0.130^{*} \\
(0.068)\end{array}$ & $\begin{array}{l}0.095 \\
(0.069)\end{array}$ & $\begin{array}{c}0.028 \\
(0.057)\end{array}$ & $\begin{array}{c}0.001 \\
(0.059)\end{array}$ & $\begin{array}{c}0.088 \\
(0.073)\end{array}$ & $\begin{array}{c}0.082 \\
(0.076)\end{array}$ & $\begin{array}{c}0.038 \\
(0.074)\end{array}$ & $\begin{array}{c}0.083 \\
(0.077)\end{array}$ \\
\hline Country group dummies: ${ }^{\mathrm{h}}$ & & & & & & & & \\
\hline Origin: Outside Europe & $\begin{array}{c}0.151 \\
(0.189)\end{array}$ & & $\begin{array}{c}0.220 \\
(0.143)\end{array}$ & & $\begin{array}{c}-0.289^{*} \\
(0.171)\end{array}$ & & $\begin{array}{c}0.157 \\
(0.183)\end{array}$ & \\
\hline Origin: Eastern Europe & $\begin{array}{l}-0.005 \\
(0.150)\end{array}$ & & $\begin{array}{l}-0.165 \\
(0.149)\end{array}$ & & $\begin{array}{c}-0.461 * * * \\
(0.162)\end{array}$ & & $\begin{array}{c}0.221 \\
(0.164)\end{array}$ & \\
\hline Origin: Crisis Country & $\begin{array}{l}-0.087 \\
(0.108)\end{array}$ & & $\begin{array}{c}-0.195 * * \\
(0.095)\end{array}$ & & $\begin{array}{l}-0.189 \\
(0.115)\end{array}$ & & $\begin{array}{c}0.255^{* *} \\
(0.121)\end{array}$ & \\
\hline Origin: Germany & $\begin{array}{c}0.087 \\
(0.106)\end{array}$ & & $\begin{array}{c}0.040 \\
(0.084)\end{array}$ & & $\begin{array}{c}-0.405^{* * *} \\
(0.107)\end{array}$ & & $\begin{array}{c}0.139 \\
(0.121)\end{array}$ & \\
\hline Origin: UK & $\begin{array}{c}0.046 \\
(0.129)\end{array}$ & & $\begin{array}{l}-0.027 \\
(0.104)\end{array}$ & & $\begin{array}{l}-0.176 \\
(0.147)\end{array}$ & & $\begin{array}{c}0.105 \\
(0.148)\end{array}$ & \\
\hline Origin: Central Europe & $\begin{array}{c}0.027 \\
(0.109)\end{array}$ & & $\begin{array}{l}-0.104 \\
(0.088)\end{array}$ & & $\begin{array}{l}-0.138 \\
(0.118)\end{array}$ & & $\begin{array}{l}0.239 * \\
(0.125)\end{array}$ & \\
\hline Residence: Eastern Europe & & $\begin{array}{c}0.001 \\
(0.159)\end{array}$ & & $\begin{array}{l}-0.074 \\
(0.164)\end{array}$ & & $\begin{array}{c}-0.401^{* *} \\
(0.183)\end{array}$ & & $\begin{array}{c}0.062 \\
(0.177)\end{array}$ \\
\hline Residence: Crisis country & & $\begin{array}{l}-0.003 \\
(0.110)\end{array}$ & & $\begin{array}{l}-0.096 \\
(0.097)\end{array}$ & & $\begin{array}{l}-0.143 \\
(0.119)\end{array}$ & & $\begin{array}{c}0.106 \\
(0.123)\end{array}$ \\
\hline Residence: Germany & & $\begin{array}{c}0.058 \\
(0.103)\end{array}$ & & $\begin{array}{l}0.141^{*} \\
(0.082)\end{array}$ & & $\begin{array}{c}-0.298 * * * \\
(0.109)\end{array}$ & & $\begin{array}{c}0.086 \\
(0.119)\end{array}$ \\
\hline Residence: UK & & $\begin{array}{c}0.024 \\
(0.114)\end{array}$ & & $\begin{array}{c}0.034 \\
(0.093)\end{array}$ & & $\begin{array}{c}-0.207^{*} \\
(0.125)\end{array}$ & & $\begin{array}{l}-0.011 \\
(0.128)\end{array}$ \\
\hline Residence: Central Europe & & $\begin{array}{l}-0.009 \\
(0.101)\end{array}$ & & $\begin{array}{l}-0.087 \\
(0.086)\end{array}$ & & $\begin{array}{l}-0.196^{*} \\
(0.112)\end{array}$ & & $\begin{array}{c}0.055 \\
(0.117)\end{array}$ \\
\hline Pseudo $\mathrm{R}^{2}$ & 0.076 & 0.057 & 0.097 & 0.081 & 0.006 & 0.056 & 0.044 & 0.031 \\
\hline Number of Observations & 243 & 242 & 246 & 245 & 246 & 244 & 236 & 234 \\
\hline
\end{tabular}

Source: IZA Expert Opinion Survey 2014.

Notes: $* * * \mathrm{p}<0.01, * * \mathrm{p}<0.05, * \mathrm{p}<0.1$. Average marginal effects from probit regressions. Standard errors in parentheses.

${ }^{a}$ The dependent variable is equal to 1 if the respondent said to be satisfied with the EU and 0 if the respondent is disappointed.

${ }^{b}$ The dependent variable is equal to 1 if the respondent agrees with the statement that the Single European Labor Market is largely achieved.

' The dependent variable is equal to 1 if the respondent's satisfaction/disappointment with the EU is affected by the state of the Single European Labor Market.

${ }^{d}$ The dependent variable is equal to 1 if the respondent believes that the economic divergence after the crisis is a long-lasting rather than a transitional phenomenon.

${ }^{\mathrm{e}} \mathrm{A} / \mathrm{A}+$ journal is defined by the Handelsblatt ranking 2011.

${ }^{f}$ Top author in Europe is defined by the RePEC ranking of top 12.5\% of authors in Europe from February 2014.

g Top level institution (in Europe) is defined by the RePEc ranking of top 12.5\% of institutions in Europe from February 2014.

${ }^{\mathrm{h}}$ Reference group for the country dummies is Scandinavia. Eastern European countries include: Bulgaria, the Czech Republic, Estonia, Hungary, Latvia, Lithuania, Poland, Romania, Ukraine, Slovakia, Slovenia, Turkey and (Ex-)Yugoslavia. Crisis countries include: Cyprus, Greece, Ireland, Italy, Portugal and Spain. Central European countries include: Austria, Belgium, France, Luxembourg, the Netherlands and Switzerland. 


\section{APPENDIX: IZA Expert Opinion Survey 2014, Questionnaire}

\section{Question 1:}

How satisfied are you with the EU?

Satisfied

Disappointed

I do not know

\section{Question 2:}

Do you think it is important to have a Single European Labor Market?

(Several answers possible)

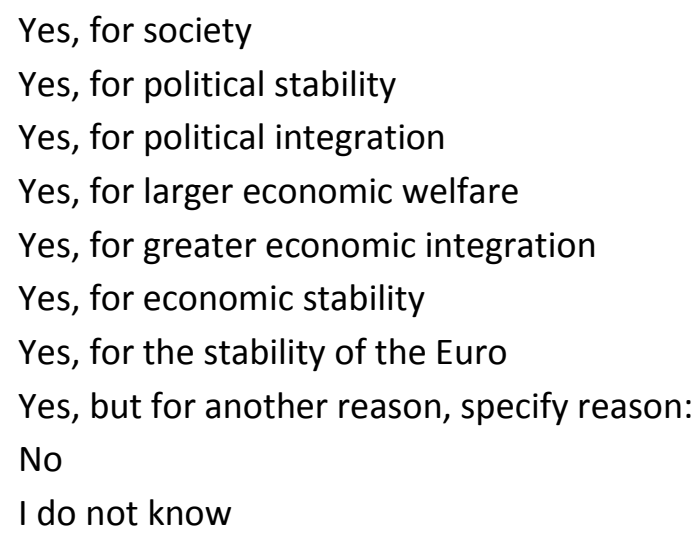

\section{Question 3:}

Please indicate whether you agree with the following statement: The goal of the Single European Labor Market is largely achieved.

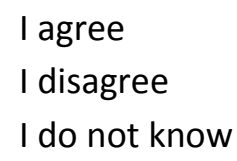

\section{Question 4:}

Your satisfaction/disappointment with the EU is affected by the state of the integration of the European Labor markets.
Yes
No
I do not know 


\section{Question 5:}

Which of the following factors do you think are essential for a Single European Labor Market?

(Several answers possible)

Intra-EU labor mobility

Larger cultural integration

Knowledge of several languages

Harmonization of social security systems on the European level

Harmonization of labor market policies on the European level

Efficient labor market policies on the national level

Lower earnings income inequality between member states

Easy and quick recognition of professional qualifications

Positive attitude by policy makers towards free mobility

Positive attitude by citizens towards free mobility

Positive attitude by policy makers towards the Euro

Positive attitude by citizens towards the Euro

Other, please specify:

I do not know

\section{Question 6:}

Which of the following factors do you consider important in order to enhance labor mobility across Europe?

(Several answers possible)

Harmonization of social security systems on the European level

Harmonization of labor market policies on the European level

Larger cultural integration

Knowledge of several languages

Harmonization of voting rights on the European level

Enhancing intra-EU mobility of third-country nationals (through, e.g., adapting existing intra-EU mobility tools to third-country nationals)

Efficient labor market policies on the national level

Easy and quick recognition of professional qualifications

Positive attitude by policy makers towards free mobility

Positive attitude by citizens towards free mobility

Other, please specify:

I do not think labor mobility across Europe should be enhanced

I do not know 


\section{Question 7:}

The economic crisis has created new economic divergence in, e.g., unemployment rates between member states. Do you think this divergence represents a longlasting phenomenon?

Yes, it will last long

No, it will rather be transitional

Other, please specify:

I do not know

\section{Question 8:}

Do you think economic or labor reform policies are important to deal with this divergence?

(Several answers possible)

In my country

Yes, economic reform policies are important

Yes, labor reform policies are important

No, economic reform policies are not important

No, labor reform policies are not important

Other, please specify:

I do not know

In general in the EU

Yes, economic reform policies are important

Yes, labor reform policies are important

No, economic reform policies are not important

No, labor reform policies are not important

Other, please specify:

I do not know

Thank you very much for completing this questionnaire! 